
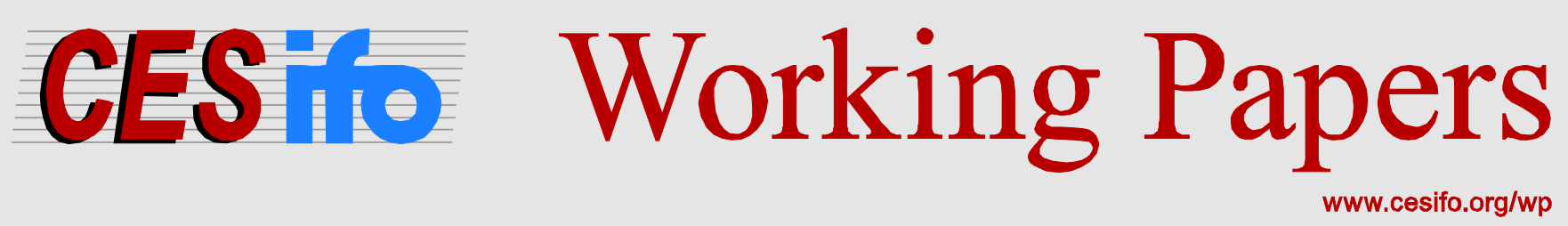

\title{
Dial 911 for Murder: The Impact of Emergency Response Time on Homicides
}

\author{
Thomas Stratmann \\ David Chandler Thomas
}

\section{CESIFO WORKING PAPER No. 6140 \\ CAtegory 2: Public ChOICE \\ OCTOBER 2016}

\footnotetext{
An electronic version of the paper may be downloaded

- from the SSRN website:

- from the RePEc website:

- from the CESifo website: WwW.SSRN.com

www.RePEc.org

www.CESifo-group.org/wp
} 


\title{
Dial 911 for Murder: The Impact of Emergency Response Time on Homicides
}

\begin{abstract}
Several theories have been offered to explain the recent declines in violent crime rates in the United States. We hypothesize that technological innovations, which improved information transmission and shortened the response time between an aggravated assault incident and treatment, reduced the cost of saving lives and caused much of the decline in homicide rates in recent decades. Using difference-in-differences and event studies, we show that improvements in emergency services (9-1-1) caused significant decreases in homicide rates. Various falsification tests support these findings.
\end{abstract}

JEL-Codes: D000, I100, K000.

Keywords: homicides, aggravated assault, response times, value of time, 9-1-1.

Thomas Stratmann

Department of Economics

George Mason University

4400 University Drive

USA - 22030 Fairfax VA

tstratma@gmu.edu
David Chandler Thomas

Department of Economics

Ball State University

2000 W. University Avenue

USA - Muncie, IN 47306

dcthomas@bsu.edu

We thank Alex Tabarrok, Garett Jones, and seminar participants at American University, Ball State University, and Washington University for helpful comments and suggestions. 


\section{INTRODUCTION}

In military medicine, "the golden hour" refers to the critical first moments that significantly reduce the mortality rate of battlefield casualties. The recognition that improved response times reduce mortality explains the significant efforts undertaken by the military to develop and introduce new medical technologies. The decline in the mortality rate of military casualties mirrors a similar trend in the recently observed homicides among civilians. Using launch dates of various stages of 9-1-1 (911) implementation, we test the hypothesis that technological innovations that lowered the cost of saving lives through shortened response times have led to reduced "lethal" aggravated assaults, and therefore, homicides. ${ }^{1}$

Homicides as well as most other major crimes peaked in the early 1970s and 1980s and have since declined. Much of the recent academic literature on crime focuses on explaining this downward trend (Blumstein and Wallman 2006; Levitt 2004). Hypotheses explaining the decrease in crime rates include increased incarceration, a larger police force, abortion (Donohue \& Levitt, 2001), and decreases in illegal substance abuse (Golub and Johnson 1994; Levitt 2004; Bowling 1999). ${ }^{2}$

We consider an additional explanation for the decline in homicide rates, an explanation based on improvements in the 911 emergency response system and the adoption of cell phones.

\footnotetext{
${ }^{1}$ We consider the launch dates of the three major improvements to the 911 emergency system.

${ }^{2}$ Among the scholarly works providing explanations for variations in homicides, researchers have studied the effect of community policing and better policing strategies (Corman and Mocan 2001; Zhao Schieder and Thurman 2002), the consequences of changing demographics (Levitt 1999), improved economic conditions (Raphael and WinterEbmer 2001; Rosenfeld and Fornango 2007), new security technologies (Farrell et al 2011), increased imprisonment (Levitt 1996; Donohue and Siegelman 1998; Liedka Piehl and Useem 2006), deterrent effects from cell phone use on the streets (Klick et al. 2012), aborted potential criminals (Donohue \& Levitt, 2001), reduced illegal substance abuse (Golub and Johnson 1994; Levitt 2004; Bowling 1999), improvements in medicine (Doerner W. , 1983), and the introduction of credit cards to distribute welfare payments (Wright et al. 2014). None of these works focuses on informational improvements in communication technology that reduced the response time for the provision of medical care.
} 
Both innovations, that is, the adoption of 911 and the adoption of cell phones, improved the quality of information and the rapidity of information transmission. We hypothesize that improvements in communication technologies shortened response times, leading to a decrease in deaths from aggravated assaults, i.e., homicides. ${ }^{3}$ Current theories that explain the recent decrease in crime, tend to apply to all types of crimes, and it would be consistent with these theories to observe similar decreases in homicides and aggravated assaults. However, Figure 1 depicts the annual percentage change in homicide and aggravated assault rates, showing a divergence in these series. The vertical axis in Figure 1 measures the percentage changes in these two crime rates relative to 1964, which is set as the base year. The graph shows that percentage changes in aggravated assault and homicide rates are highly correlated from 1964 to about 1974, after which the two series diverge. Aggravated assault rates rose during the early 1980s and then, after a brief leveling off, continued to climb into the early 1990s. The graph further shows that homicide rates stopped increasing in 1974, leveled off with two bumps, which are associated with the increases in aggravated assaults around 1980 and 1990, and then steadily declined after the early 1990s. Figure 1 further shows that in 2014, the aggravated assault rate is more than twice the size than in 1964. However, homicides in 2014 are only at 92 percent of 1964 levels.

Our model predicts the divergence in homicide and aggravated assault rates observed in Figure 1, because after 1973, many cities had adopted emergency 911 services, which reduced response times and improved information transmissions, thereby lowering deaths associated with crimes. Further, our model predicts the continued decline in homicides following the

\footnotetext{
${ }^{3}$ The FBI's Uniform Crime Reporting (UCR) website defines aggravated assault as “an unlawful attack by one person upon another for the purpose of inflicting severe or aggravated bodily injury.” The UCR site also states, “...this type of assault is usually accompanied by the use of a weapon or by other means likely to produce death or great bodily harm.” (Federal Bureau of Investigation 2011)
} 
introduction of additional 911 innovations due to the continued shortening of response times. Our results provide evidence that all three 911 innovations considered in this paper have contributed to the observed decreases in homicides. Further, our findings show that 911 innovations have changed the number of aggravated assaults. This is due in part because any assault that does not result in a homicide is by definition an aggravated assault. Thus, by pure mechanics, saved lives implies more aggravated assaults. However, we also report evidence that suggest that the initial 911 innovation led to more reporting of aggravated results, while the more recent, cell-phone related innovations appear to have had a deterrent effect on aggravated assaults.

We collected annual data for 112 of the largest U.S. cities from 1964 to 2014, indicating the year when a city adopted Basic 9-1-1 (Basic 911), Enhanced 9-1-1 (E911), and wireless (GPS 911) emergency services. Crime data come from the FBI. To identify a causal effect of these technological innovations on homicides, we employ difference-in-differences and event studies. Results show that the technological innovations had a large quantitative and statistically significant effect in reducing homicides and increasing aggravated assaults. The event study results show quantitatively important drops in homicide rates in the year of the introduction of each technological innovation.

We also test whether any changes in violent behavior, such as a change in the use of guns vs. knives, can explain the divergence in homicides and aggravated assaults. Further, we use a number of falsification tests to analyze the robustness of our findings. The results from the sum of these tests support our hypothesis that response-time-reducing 911 services contributed significantly to the decline in homicide rates. 


\section{INSTITUTIONAL FRAMEWORK AND HYPOTHESES}

\section{A. Deployment of 911}

The first proposal for a nationwide emergency phone number came from the National Association of Fire Chiefs in 1957. A decade later, officials from the Federal Communication Commission (FCC) met with the American Telephone and Telegraph company (AT\&T) representatives, to determine a method for implementing a universal emergency number. At that meeting, AT\&T proposed the number 911 for an emergency call number because it was short, memorable, easy to dial, and was never used as an area code or as a service number.

In 1968, Nome, Alaska, launched the first citywide 911 call-system, initiating the pattern for the adoption and implementation of 911 services at the city level. In March 1973, the White House's Office of Telecommunications issued a national policy statement, encouraging the adoption of 911, and authorized the establishment of a Federal Information Center (FIC) to assist in implementing this emergency service. By 1979, approximately 26 percent of the U.S. population had 911 access. By 1987, approximately 50 percent of the U.S. population had 911 services, with most major metropolitan areas covered. Currently more than 96 percent of the U.S. population has access to 911 services (National Emergency Number Association, 2013).

\section{B. 911 Innovations}

There are three generations of 911 services. The first generation of 911 was implemented beginning in the late 1960s and introduced the three-digit number 911 as the single phone number for all emergency calls (Basic 911). This communication system was a simple operatorassisted call transfer service. A caller would request fire, police, or ambulance, and the operator would transfer the call to the appropriate service provider. 
The second generation of 911, called Enhanced 9-1-1 (E911), appeared in the late 1970s, and included the creation of dedicated call centers with monitors that displayed the home phone number and address of the caller. Using this improved technology, trained call-center personnel directly dispatched firefighters, police, or an ambulance to the caller's address.

As cell phones began to replace landlines, demand for 911 wireless support emerged. The rollout of 911 support for cell phones required the implementation of two technologies. In Phase I of this third generation of 911, wireless providers attempted to pinpoint the location of a caller by triangulating with nearby cell towers, and then providing caller coordinates to the call center when connecting the 911 call. However, the technology was inaccurate, since it could triangulate the caller's location to only within hundreds of yards. Phase II wireless support (GPS 911), was in response to a federal mandate that all newly manufactured cell phones include a global positioning system (GPS) chip that had to remain active as long as the phone had power. With this technology, users of cell phones could reach 911 dispatch centers even without an active wireless plan. Although GPS 911 first appeared in the early 2000s, the technology remains unavailable in several urban areas and where available, it operates intermittently and with delays.

\section{Hypotheses}

We hypothesize that Basic 911, E911 and GPS 911 led to significant reductions in homicide rates.

The mechanism that led to the declines in homicides through 911 innovations is the subsequent and immediate reduction in response time. With the adoption of these communication interventions, individuals with serious injuries were able to more easily and quickly report the injury, benefited from faster emergency services notification and emergency services travel time, were more likely stabilized by emergency services, and were more likely to 
reach an emergency room alive to receive life-saving medical treatments. Each subsequent innovation is an incremental improvement over the previous 911 technologies.

\section{Causal Channels and Mechanisms: Response Times}

Before the introduction of 911 services, an individual seeking assistance in an emergency would first have to locate the correct phone number, or dial " 0 " to reach an operator, who typically was an employee of the telephone company. The introduction of Basic 911 reduced response times by making it easier for a victim or a witness to remember the three digits that could connect them to the appropriate emergency service. A county-level study performed in 1984 reported that, without the availability of 911, a victim’s success rate of reaching the appropriate emergency service was 63 percent, while with an active 911 service, the success rate increased to 82 percent — an increase of over 30 percent. In addition, the introduction of 911 increased the probability of using a dedicated emergency phone number from 40 percent to 74 percent (Mayron et al 1984), which was another contributor to reducing response times.

Blackwell and Kaufmann (1984) document the impact of shortening response times on reducing deaths rates. For example, they estimate that the likelihood of death increases by 19.5 percent with each additional passing minute within the first twelve-minute window after a caller has reached 911. In the minutes past this window, increases in death rates continue at lower rates, and eventually level off.

E911 generated an additional improvement in response time by speeding up the dispatching service performed by the operator. Using the displayed home address of the caller, the operator could dispatch police, fire, and ambulance services even if the caller was unable to speak. Evidence of the effectiveness of reduced dispatch time due to E911 comes from Athey and Stern (2002). These authors find that after the introduction of E911 in specific Pennsylvania 
geographic areas, survival rates of heart attack victims significantly improved and they attribute these increased survival rates to faster response times, made possible by the introduction of E911. Further, Joslyn, et. $\mathrm{al}^{4}$ measure improvements in response time resulting from the implementation of E911 in Iowa, and find that after the introduction of E911, the percentage of calls with response times of less than six minutes increased by 22.9 percent.

In the early 2000s, as callers started to replace their landline home phones with cell phones, more and more emergency calls came from cell phones and the issue of pinpointing the location of cell phone callers received attention in the press. An article from a 2001 issue of the Washington Post described the situation as “... wireless phones without the Global Positioning System (GPS) support of wireless E911 service is eroding the ability of emergency services to locate the caller and insure the timely arrival of help” (Foig-Franzia 2001).

GPS 911 improved response times, because when cell phones had a GPS chip, location identification was improved. Moreover, if callers changed location after they had placed a 911 call and had their cell phone with them, the changed location could be tracked.

However, GPS 911 faces technological challenges. These include the loss of GPS signals in high-rise urban areas, the difficulty in identifying the floor of a multi-story building from which a wireless call originates and the incompatibility or lack of standardized communications among cell phone manufacturers, wireless network providers, and 911 systems software.

${ }^{4}$ Joslyn, Sue A., Pomrehn, Paul R., MD, Brown, Donald D., MD, "Survival from Out-of-Hospital Cardiac Arrest: Effects of Patient Age and Presence of 911 Emergency Medical Services Phone Access”, American Journal of Emergency Medicine, May 1993, Vol 11, Number 3, Pages 200-206 


\section{EMPIRICAL METHODS}

\section{A. Data Sources}

We analyze annual data from 1964 to 2014. By focusing on this 51-year period, our window of analysis includes several years prior to the implementation of the first 911 emergency services and extends to recent times.

In our sample, cities are the unit of analysis because the rollout of emergency communication services began at the city level and because both city-level crime and weapon data are available starting with 1964. After the 1968 AT\&T announcement of the emergency 911 number, local governments at the city level chose the year of Basic 911 implementation. The rollout of E911 services also occurred at the city level, beginning in 1982 in Alameda, California and St. Louis, Missouri. For the cities in our data set, the rollout of GPS 911 occurred mostly at the city level as well.

We collected city-level homicide and aggravated assault data, and data on the type of weapon used in aggravated assaults from reports provided to the FBI by U.S. city police departments. Prior to the early 1980s, the Uniform Crime Reporting (UCR) data at the county level are not accurate for all counties, because in some counties not all police departments reported statistics or they reported incomplete statistics. This was primarily the case for police departments located in smaller cities. However, the data reported by police departments located in the largest cities and data reported for the more serious crimes, such as murder and aggravated assaults, are reliable even prior to 1980 (Pridemore 2005). In our study, we use data from police department reports from large cities and we are thus using reliable data. The selection criteria for inclusion of a city in our dataset were those cities with population sizes over 200,000 in at least one year of our sample period, and complete or nearly complete observations dating back several 
years before their implementation of any 911 services. We identified 112 cities that met these criteria. $^{5}$

To identify the launch dates of Basic 911 and E911 services, we contacted local call centers and collected launch dates from local newspaper archives. Start dates for the launch of GPS 911 come from two Federal Communication Commission (FCC) reports, indicating the earliest dates when cities in our sample could make use of these services. For GPS 911, call centers could only offer this service when they had support for GPS services, and when the local wireless providers had the technology to transmit the GPS coordinates. Once both conditions were met, a city offered GPS 911. We define a 911 innovation as being implemented when a city had the emergency service in place for more than half of the year.

Figure 2 shows a graphical presentation of the rollout of the three 911 services for the 112 cities. Basic 911 services began to roll out in 1968 and remained active in some cities as late as 2002. The added capability for dispatchers to observe the home address and directly dispatch emergency personnel (E911) started to appear in 1978, and continued to rollout over the following fifteen years, with a few cities still operating the service in 2014. In a few cities, the support for cell phones started in the late 1990s and then rolled out rapidly after 2003 when GPS data from smart phones began to appear on dispatcher displays (Blumberg, Luke, Ganesh, Davern, \& Boudreaux, 2012). In our sample, about 100 cities had GPS 911 service by 2014.

One feature of each rollout is that each new emergency innovation augmented the previous innovation (Figure 2). Thus, once a city introduced E911 services, the features of the existing Basic 911 services remained active. Some cities implemented E911 without first

\footnotetext{
${ }^{5}$ These 112 cities have crime information for virtually all of our sample years. Exceptions are a few cities for which we have data dating back only to the 1970s.
} 
implementing Basic 911. In contrast, cities adopting GPS 911 already had either Basic 911 or E911 services.

A potential cause for the declining homicide rates might be changes in the mix of weapons used to commit aggravated assaults. Guns are the most lethal weapons, followed by knives, suggesting that a decline in the use of guns in aggravated assaults might explain the decline in homicides. ${ }^{6}$ To address this potential concern, we collected data on weapons used in each homicide and aggravated assault incident. These data are available from the aforementioned police department reports and we aggregated incidence data to the city and year level.

Figure 3 presents the annual percentage of guns used in aggravated assaults between 1964 and 2014 in the 112 cities analyzed in this paper. The graph shows that gun use in aggravated assaults hovers around 25 percent. Figure 3 does not show a systematic decline in gun use between 1964 and 2014, and even at the peak of homicide rates, in the early 1980s, gun use is lower than it is in 2014. This suggests that these aggregate numbers do not show a decline in gun use, which potentially could have explained the decline in homicide rates presented in Figure 1. In our empirical analysis, one of our controls is the differences in the weapon mix between cities and over time.

\section{B. Estimation Methods}

We estimate the model

(1) $\quad \ln \mathrm{y}_{\mathrm{it}}=\boldsymbol{\beta}$ CommunicationInnovation ${ }_{\mathrm{it}}+\boldsymbol{\alpha} \mathbf{X}_{\mathrm{it}}+\mu_{\mathrm{i}}+v_{\mathrm{t}}+\varepsilon_{\mathrm{it}}$

\footnotetext{
${ }^{6}$ However, Harris, Thomas, Fisher, \& Hirsch, 2002, found no support for the hypothesis that a change in weapon use explains decreases in homicides between 1960 and 1999.
} 
where $y_{i t}$, depending on the specification, is either the number of homicide per 100,000 residents in city $i$ in year $t$, or the number of aggravated assaults per 100,000 city residents.

The vector CommunicationInnovationit includes three indicator variables for each of the 911 innovations. They are Basic911, E911, and GPS911. Given that we express the dependent variable as the natural logarithm, the estimated coefficients on these 911 innovations measure the percentage impact of these services on the dependent variable in equation (1). ${ }^{7}$

The point estimate on Basic911 measures the impact of moving from a situation of no 911 services to Basic 911. In our coding of the data, once a city adopts E911 after having already adopted Basic 911, the E911 indicator switches from “0” to "1", and the Basic911 indicator remains "1". The estimated coefficients on all 911 innovations measure the percentage impact of that innovation relative the 911 service that existed prior to that innovation.

All regressions include city and year fixed effects, $\mu_{\mathrm{i}}$ and $v_{\mathrm{t}}$ respectively. Year fixed effects capture medical improvements that are largely systemic. City fixed effects capture timeinvariant city observable and unobservable variables, such as a violent or peaceful city culture.

The identifying assumption in our model is that city trends are parallel. ${ }^{8}$ We test the validity of our identifying assumption, as well as offer several falsification tests.

The $\mathbf{X}_{\mathbf{i t}}$ vector in the regression model includes crime specific variables such as the type of weapons used in homicides and aggravated assaults, aggregated to the city and year level. We include these variables to control for the possibility that changes in weapon use over time might affect homicide or aggravated assault rates. Specifically, we include the percent of

\footnotetext{
${ }^{7}$ The exact percentage impact is given by $\left.(\exp (\beta)-1)\right)$.

8 The parallel trends assumption is not met when those cities who are on a steeper path to increased homicides, for example, because of an inflow of gangs, are more likely to adopt 911 services. An increase in gangs changes city homicide trends if gangs change a city's ratio of homicides to aggravated assaults.
} 
aggravated assaults with gun use, the percent with knives use, and the percent with the use of fists or other body parts. The category "other weapon” is the reference category.

The $\mathbf{X}_{\mathbf{i t}}$ vector also includes socioeconomic city characteristics such as real per capita income, population density, and race. We measure annual city population density as the number of city residents per year divided by the number of square miles of land in a city per year. For each city of our sample, we obtained these city square mile data from county records of city expansions.

Annual city median per capita income comes from U.S. Census records and we measure this variable in real year-2000 dollars. The U.S. Census Bureau is also the source for annual citylevel race data.

Another control variable in our regression model is the household adoption rate of a cell phone as the primary phone- that is, households that replaced their landline telephone service with wireless cell phones. For 2005 and from 2007 to 2014, these cell phone adoption statistics are available from three National Center for Health Statistics Reports (Blumburg, et al., 2011). We linked these data to the cities in our sample. Using a binomial interpolation from the trend between 2005 and 2014, we estimated adoption rates for the years without data availability prior to 2005.

For our second empirical design, we test our hypothesis by estimating the discontinuity in homicides and aggravated assaults at the launch event of each 911 service.

(2) $\quad \ln \mathrm{y}_{\mathrm{itj}}=\boldsymbol{\beta}$ CommunicationInnovation ${ }_{\mathrm{itj}}+\varphi \mathrm{f}\left(\right.$ trend $\left._{\mathbf{t j}}\right)+\boldsymbol{\alpha} \mathbf{X}_{\mathbf{i t j}}+\mu_{\mathrm{i}}+v_{\mathrm{t}}+\varepsilon_{\mathrm{itj}} \quad \mathrm{j}=-3, \ldots 0 \ldots,+3$

In this event study design, we estimate separate regressions for each of the three communication innovations. We estimate these regressions with either log homicides or log 
aggravated assaults as the dependent variable. We are using a narrow window, spanning seven years. This window includes three years prior to the launch of a 911 innovation, the year of the launch, and three years after the launch of a 911 innovation. We use the same set of control variables as in the difference-in-differences model, namely the weapon mix and the socioeconomic characteristics, as well as city fixed effects $\mu_{\mathrm{i}}$. We also include an indicator, $v_{\mathrm{t}}$, for the calendar year that a city is observed in our time window.

In equation (2), $f\left(\right.$ trend $\left._{t j}\right)$ represents three functional forms for trends. They are a linear trend, a quadratic trend, and separate trends before and after the launch of each 911 service.

In both models (1) and (2), we cluster standard errors at the city level. As a robustness check, we also cluster standard errors at the state level. Table A1 in the Appendix lists the 112 cities included in our data. Table 1 provides descriptive statistics of our variables.

\section{Results}

Table 2 shows the estimates from the difference-in-differences model with log homicides as the dependent variable. All specifications include both city and year fixed effects, with standard errors clustered at the city level. ${ }^{9}$

In Table 2, the regression specification reported in the first column includes all three 911 innovations. To capture the city and year specific level of violence, we also include aggravated assaults. ${ }^{10}$ All coefficients on these 911 innovations are negative, as hypothesized, and both the Basic 911 and GPS 911 estimates are statistically significant at the one percent level, indicating

\footnotetext{
${ }^{9}$ In unreported specifications, we also cluster the standard errors at the state level, both in Table 2 as well as in subsequent tables. For all results, the corresponding levels of statistical significance are very similar to those when clustering at the city level and therefore inference is very similar when we cluster standard errors at the state level. ${ }^{10}$ Our estimation results in Table 2 are robust to excluding aggravated assaults from these specifications.
} 
that these communication innovations reduced homicide rates. Given that the omitted category is no 911 emergency services, the negative and statistically significant coefficient on Basic 911 indicates that this innovation reduced homicides relative to a situation without city-wide Basic 911 services. The negative coefficient on E911 indicates that the introduction of E911 reduced homicides relative to Basic 911, but Table 2, column 1 shows that this reduction is not statistically significant. The negative and statistically significant GPS 911 coefficient indicates that the introduction of GPS 911 resulted in an additional drop in homicides, that is, an additional drop in homicides after the introduction of Basic 911 and E911. The cumulative effect of all three innovations is computed by summing their coefficients. The sum of these estimates indicates that once all three innovations were introduced, homicides rates are roughly 35 percent lower than they would have been without the introduction of these innovations.

Table 2, column 2 adds the weapon-use variables to the specification in column 1 . This changes the sample size relative to column 1, because we are missing weapons data for some years. The results show that the coefficients of the 911 adoptions in column 2 of Table 2 remain with similar magnitudes and statistical significance as those in column 1 of the same table. The overall similarity of the findings between columns 1 and 2 shows that there is little correlation between the type of weapons used and the adoption of new communication technologies. Further, the results in column 2 show that the declines in homicides associated with 911 innovations cannot be attributed to changes in the type of violence committed in aggravated assaults. The point estimates on the weapons variables show that relative to the omitted category 
“other weapon," aggravated assaults that involve the use of guns have the largest effect on homicides, followed by knives. ${ }^{11}$

Table 2, column 3 adds various socioeconomic characteristics to the specification in column 1. Relative to column 1, the coefficients and corresponding clustered standard errors are virtually unchanged for the three 911 communication innovations, indicating that the adoption of 911 services are uncorrelated with our included observable socioeconomic characteristics.

Table 2, column 4 includes all of our control variables. Again, relative to the first three specifications, we do not observe much of a change in the magnitude and the level of statistical significance for the three 911 innovations. Given that we estimate log-linear specifications, the magnitude of the estimated coefficients on the communication innovations in Table 2, column 4 imply that the adoption of Basic 911 services led to a $15.4(\exp (-0.167)-1)$ percent decrease in homicide rates. While the adoption of E911 resulted in only an additional 3.7 percent decrease, the adoption of GPS 911 services resulted in an additional 19.6 percent decrease in homicide rates (Table 2, column 4). All three coefficients on the emergency services innovations are jointly statistically significant, and summing all three coefficients implies that that the adoption of all three emergency services resulted in a 35.5 percent decrease in homicides.

Figure 4, Panels A to C show a graphical presentation of the key results in Table 2, column 4. To understand the dynamics underlying the effectiveness of 911 innovations in reducing homicides, Figure 4 shows the estimated coefficients when substituting each of the 911 indicators in Table 2, column 4 with seven separate indicators. These seven separate indicators are comprised of three indicators for the each of the three years prior to the adoption of the

\footnotetext{
${ }^{11}$ For the period analyzed in this paper, the FBI reports the type of weapon used in an aggravated assault, but not the type of weapon used in a homicide. Thus, we use the former measure in our regressions.
} 
technology, one indicator for the year of the launch of the technology, and three indicators for the first two years and three-plus years after the launch of the technology. ${ }^{12}$ The plots in the panels in Figure 4 display the point estimate for each set of these indicators for each of the three 911 innovations. Further, the plots show the 95 percent confidence intervals based on clustered standard errors at the city level. Panels A and C, corresponding to the Basic 911 and GPS 911 innovations, show that homicide rates are relatively constant prior to the introduction of the new technology, then drop sharply following the launch of a 911 innovation, and that homicide rates stay relatively constant in the following years.

For the effects of the E911 innovation the individual plots of the annual regression coefficients are especially informative. The regression results in Table 2 seem to indicate that the E911 innovation was not effective with respect to reducing homicides. However, Table 4, Panel B shows that once E911 was launched, there was a sharp drop in homicides, which remains below pre-launch homicide rates in the two years after the launch. Only in the three-plus year category are homicides above pre-launch levels. Thus, it is this latter increase in homicides that explains why the estimated coefficient on E911 in Table 2 is small, and the increase in the threeplus-years category might be due to factors other than the E911 introduction. In sum, all three panels in Figure 4 are consistent with the hypothesis that the introduction of each iteration of 911 led to an immediate and significant decreases in homicide rates.

Table 3 tests whether the parallel trends assumption holds for the specifications shown in Table 2. The first four columns include city specific time trends and the last four columns include city specific quadratic trends. We find that most estimated coefficients on the Basic 911

\footnotetext{
12 The number of years in the three-plus category is either the number of years until the introduction of the next 911 innovation, or the number of years up to the last year included in our data set.
} 
and GPS 911 innovations remain negative and statistically significant and at similar magnitude levels as in Table 2. The estimated coefficients on E911 increase in size relative to Table 2, and are statistically significant. Of the 24 coefficients on the 911 innovations reported in Table 3, only two coefficients are substantially smaller than those in Table 2, which are the Basic 911 coefficients in column 3 and the GPS 911 coefficient in column 7. Therefore, using both linear and quadratic trends, overall the point estimates on the 911 innovations remain quantitatively important, suggesting that this difference-in-differences model largely conforms to the parallel trends assumption.

Table 4 presents specifications similar to Table 2, but the dependent variable of the regression results shown in Table 4 is the log aggravated assault rates. All regressions include city and year fixed effects, and, as in the previous tables, standard errors are clustered at the city level.

In Table 4, column 1, besides the unreported city and year fixed effects, only the three 911 innovations are included. Table 4, column 2 adds controls for the weapons used in crimes committed in a given year and city; column 3 adds to the column 1 specification controls for socioeconomic characteristics of the city in a given year; and column 4 adds all control variables from the previous two columns.

Table 4 shows that the point estimates on the Basic 911 and E911 innovations have a positive sign and are statistically significant, indicating that the introduction of both iterations of 911 led to an increase in the reporting of aggregate assaults. The coefficients on both of these emergency services innovations are of similar magnitude and statistically significant across all four specifications, and thus are robust to the inclusion of different control variables and slightly different sample sizes that are due to data availability. The introduction of Basic 911 led to about 
a 10 percent increase in the reporting of aggravated results, and the subsequent introduction of E911 led to an additional 14 percent increase in the reporting of aggravated assaults (Table 4, column 2).

However, the introduction of GPS 911 is associated with a subsequent 12 percent decrease in aggravated assault reporting. ${ }^{13}$ This latter finding is consistent with the hypothesis that cell phone use, especially when combined with GPS 911, has a deterrent effect on crime. GPS 911 could not improve the reporting of domestically located aggravated assaults, given that most individuals, by the introduction of GPS 911, had landlines with access to either Basic 911 or E911. However, GPS 911 could have an influence on the reporting of aggravated assaults observed outside of a home, but the availability of cell phones used outside of the home, combined with the ability to use GPS 911, also had the potential to deter criminal activity.

The introduction of Basic 911 was at a time when there were only landlines, and thus besides calling from public phone booths, individuals had no other choice than to call emergency services via landlines. The introduction of E911 resulted in faster response times, given that a caller’s landline address was displayed on the dispatchers’ monitors, (but still limited emergency calls to those from home landlines and phone booths). In contrast, GPS 911 allowed individuals to call emergency services from outside their residence. GPS 911 increases the probability that an offender will be captured, because GPS 911 reduces police response time to street crimes. Thus, when potential violent street offenders know that cell phone users have a quick way to reach the police, via GPS 911, their incentive to commit a crime decreases. Our estimates seem

\footnotetext{
${ }^{13}$ For Table 4, we also tested the parallel trends assumption, as we did for the results in Table 2 . We do not report the results here, but those results show that, consistent with the parallel trends assumptions, the coefficients on the 911 innovations in the aggravated assault regressions are similar, regardless whether or not we include linear or quadratic trends.
} 
to indicate that for GPS 911, the deterrent capability of cell phone use with GPS 911 capabilities outweighed the reporting of previously unreported aggravated assaults.

Table 5 includes regression results from our falsification tests, that have the logs of robbery (column 1), burglary (column 2), larceny (column 3), and vehicle theft (column 4) as dependent variables. Given that these crimes are classified as not involving physical assault and subsequent physical harm that can be addressed by emergency medical services, we predict that 911 emergency services do not have much, if any, effect on these crimes. Moreover, 911 emergency services are also unlikely to have a reporting effect, that is, the availability of 911 is unlikely to increase the likelihood that these crimes are reported. This is because robbery, burglary, larceny and vehicle theft are property crimes. Victims of these crimes have an incentive to report these crimes to obtain insurance payments and thus the availability of emergency 911 is unlikely to provide a strong additional incentive for reporting of these property crimes.

The estimation results from these specifications are consistent with our hypotheses. With the exception of a significant negative effect on burglaries with GPS 911, none of the other point estimates on the 911 innovations are negative. All of these twelve estimates are relatively small when compared to the corresponding estimates in the homicide and assault regressions and none are statistically significant. These findings lend support to the hypothesis that the 911 innovations reduced homicides and not factors unaccounted for in our regression framework.

To strengthen the causal interpretation of our findings, we take advantage of the response-time discontinuity generated following the introduction of each technology. We thus use event studies to estimate the effect of 911 services on homicides and aggravated assaults. Table 6 presents the event study results with homicides as the dependent variable. The table reports the discontinuity estimates from nine regressions; we estimate one regression for 
each of the three 911 innovations, and for each of these innovations we estimate one specification with a linear trend, another specification with a quadratic trend, and a third specification with a piecewise linear trend. The latter specification allows for a separate linear trend before and after the launch of each innovation. All specifications include the same control variables as the specification in Table 2, column 4, and we cluster standard errors at the city level. For each city with the 911 innovation under consideration, we include three years prior to the launch of the 911 technology, the year of the launch, and three years that followed the launch.

In Table 6, each of the point estimates shows the marginal effect of a 911 innovation with respect to reducing homicides over the previous 911 innovation or lack of 911 services.

All estimated coefficients on the 911 innovations are negative in Table 6, as hypothesized. The statistically significant -0.183 coefficient for Basic 911 , using a piecewise linear trend, implies a seventeen percent reduction in homicide that can be attributed to this 911 innovation. This magnitude is of very similar magnitude to the corresponding finding in the difference-in-differences estimates in Table 2. The coefficients for E911 and GPS 911 are also statistically significant with the coefficient on E911 also implying a 17 percent reduction in homicides, and the coefficient on GPS 911 implying a 37 percent reduction in homicides, relative to the previous 911 innovation.

Figure 6 graphically depicts our event study results that are based on the separate linear trends before and after the 911 launches. Figure 6, Panel A shows the results for Basic 911 adoption, Panel B the results for E911 services, and Panel C the results for GPS 911. To generate these graphs, we create equal-sized bins in which we put our 112 cities. Next, we plot the corresponding data points and estimated regression slopes from Table 6 for the three years 
prior to the adoption of each service and both the adoption year and the three years following the adoption.

Figure 6, Panel A shows that the trend on homicide rates has a small positive slope prior to the adoption of Basic 911 services, dropped with the introduction of this 911 service, implying a 17 percent reduction in homicide rates, and continues with a small positive slope after the introduction of Basic 911. Figure 6, Panel B shows the effect of the introduction of E911 and presents a picture similar to that in Panel A. Panel C shows the discontinuity estimates for the introduction of GPS 911. In all three panels, the pattern is similar, with small increasing trends in homicide rates and sharp drops upon the launch of each innovation. Despite the small increasing trends, in all three panels, the homicide rate is lower in year three after the launch, than in each of the three years prior to the launch.

Table 7 shows the event study estimates for aggravated assaults, using the same presentation pattern of results as in Table 6. Figure 7 presents a graphical presentation of the specifications in Table 7 that correspond to the two separate linear trends specifications. In the linear and quadratic trends specifications, we find that the introduction of Basic 911 and E911 led to a between six and ten percent increase in the reporting of aggravated assaults. While the coefficients in the difference-in-differences regressions for these interventions were somewhat larger than reported here, these findings are broadly consistent with those in Table 4. Moreover, Figure 7 shows that in the two linear trends specifications, which is our most flexible functional form estimated, no large jump in aggravated assaults occurred immediately after launch of Basic 991 and GPS 91, which is consistent with the reported point estimates in Figure 5. However, Figure 7 shows that there is a noticeable increase in the reporting of aggravated assaults after the 
E911 introduction. However, the point estimate on E911 is not statistically significant in the two linear trends specifications, as shown in Table 7.

\section{Case studies}

To document how the introduction of 911 has changed homicide rates in specific cities, we show how homicides evolved over time in two of our sample cities.

Figure 8 shows the log homicide rates for Mobile, Alabama from 1964 to 2014. The figure shows that the introduction of Basic 911 coincides with an immediate 29 percent fall in the homicide rate with further declines in the years that followed. The timing of the introduction of E911 in Mobile, Alabama coincides with the rise in homicides and aggravated assaults attributed to the crack cocaine epidemic. Here, the numbers show that the replacement of Basic 911 with E911 in the late 1980s, a time when crime was rising rapidly in the US, is associated with an increase in homicide rates. While the Mobile experienced only a relatively small increase in homicides from 1988 to 1991, homicides increased nationwide by over 160 percent during the same period. Figure 8 lends support to the hypothesis that GPS 911 had a significant impact in reducing homicides. The graph shows that in Mobile, homicides declined by 42 percent immediately after the rollout of GPS 911 in 2009.

Figure 9 shows the log homicide rates for Cincinnati, Ohio. Homicide rates did not drop on the launch of Basic 911 in 1974, though homicide rates declined significantly over the next decade. After a rise in homicide rates during the mid-1980s, the introduction of E911 coincided with an immediate drop of 33 percent in homicide rates. Further, the rollout of GPS 911 in 2007 is correlated with an immediate and significant drop of 36 percent in homicide rates.

These two examples show that the 911 innovation effects we are reporting in our regression results are also noticeable when comparing unconditional city-level homicide means 
before and after the introduction of 911. Moreover, these anecdotes provide additional support for the hypothesis that declines in homicides associated with 911 innovations were largely due to saving lives, and that these declines cannot be solely contributed to, for example, changing demographics, better policing strategies, or less substance abuse.

\section{Conclusions}

While the level of violent crimes, measured as aggravated assaults, is 219 percentage points higher in 2014 than in 1964, homicides in 2014 are eight percentage points lower than in 1964 (Figure 1). In this paper, we find support for the hypothesis that the introduction of 911 services explains much of the decrease in homicide rates. Moreover, the introduction of 911 provides an explanation for the divergence between aggravated assault and homicide rates that started in the early 1970s. In our analysis, we document the economic value of shortening response times and the benefit of decreasing the time cost of emergency responses. We show that several 911 innovations lowered the production costs of saving lives, and subsequently led to fewer homicides.

The empirical results in this paper indicate that reductions in emergency response times played a significant role in reducing U.S. homicides over the past 45 years. Both of our empirical approaches, the difference-in-differences and event studies, support the hypothesis that 911 emergency services and the innovations that occurred in providing these services significantly reduced homicide rates. Moreover, our falsification tests provide additional support for the causal interpretation of our findings. 
The reported 911 effects are quantitatively important, suggesting more than a 34 percent ${ }^{14}$ to 56 percent ${ }^{15}$ decrease in homicides that can be attributed to the 911 systems and associated reductions in response times. One simple approach to illustrate the benefits of 911 is to use our estimates to quantify the lives saved by 911 innovations. Such an exercise shows that in 2014, without 911 emergency services, the number of homicides in our sample cities would have been more than 13,000 homicides, instead of the reported 5,872.

Besides documenting the effect of the 911 communication innovations, our findings suggest that there might be opportunities for further reductions in homicide rates by increasing the coverage of the emergency response systems and emergency services through the continued adoption of GPS cell phone support in call centers. For future research, it is of interest to study other gains from 911 innovations. For example, future work might analyze the effect of 911 innovations on reducing accidental death rates.

${ }^{14}$ A 34 percent drop in homicide rates is predicted from the estimation results reported in Table 2.

${ }^{15}$ A 56 percent drop in homicide rates is predicted from the estimation results with linear trends in Table 3. 


\section{REFERENCES}

American College of Surgeons. (2012, August 24). Verified Trauma Program. Retrieved April 20, 2013, from AHD.COM: http://www.ahd.com/definitions/prof_acscot.html

Athey, S., \& Stern, S. (2002). The Impact of Information Technology on Emergency Health Care Outcomes. RAND Journal of Economics, 33, 399-432.

Bazzoli, G., Madura, K., Cooper, G., McKenzie, E., \& Maier, R. (1995). Progress in the Development of Trauma Systems in the United States: Results of a National Survey. JAMA, 273(5), 395-401.

Becker, G. S. (1968). Crime and Punishment. Journal of Political Economy, 76(2), 169-217.

Blackwell, Thomas H., MD, Kaufman, Jay S., MD, "Response Time Effectiveness: Comparison of Response Time and Survival in an Urban Emergency Medical Services System”, Academic Emergency Medicine, 2002, 9(4), 288-295.

Blumberg, S. J., Luke, J. V., Ganesh, N., Davern, M. E., \& Boudreaux, M. H. (2012). Wireless Substitution: State-Level Estimates From the National Health Interview Survey, 2010-2011. U.S. Department of Health and Human Services, Centers for Disease Control and Prevention. Washington, DC: National Center for Health Statistics.

Blumburg, S. J., Luke, J. V., Ganesh, N., Davern, M. E., Boudreaux, M. H., \& Soderberg, K. (2011). Wireless Substitution: State-level Estimates From the National Health Interview Survey, January 2007 - June 2010. U.S. Department of Health and Human Services, Centers for Disease Control and Prevention. Washington, DC: National Center for Health Statistics.

Blumstein, A., \& Rosenfeld, R. (1998). Explaining Recent Trends in U.S. Homicide Rates. The Journal of Criminal Law and Criminology, 88(4), 1175-1216.

Blumstein, A., \& Wallman, J. (2006). The Crime Drop in America. Cambridge, MA: Cambridge University Press.

Bowling, B. (1999). The Rise and Fall of New York Murder: Zero Tolerance or Crack's Decline? British Journal of Criminology, 39(4), 531-554.

CDC. (2014, October 11). wonder.cdc.gov. Retrieved October 11, 2014, from CDC Wonder: http://wonder.cdc.gov/cmf-icd9.html

Centers for Disease Control and Prevention. (2012). Guidelines for Field Triage of Injured Patients. U.S. Department of Health and Human Services.

Corman, H., \& Mocan, H. N. (2000, June). A Time-Series Analysis of Crime, Deterence, and Drug Abuse in New York City. American Economic Review(90), 584-604.

Cowley, R. (1975). A total emergency medical system for the state of Maryland. Maryland State Medical Journal, 27, 37-45.

Cromie, W. J. (2004, December 16). Ninety Percent of U.S. Wounded Survive. Harvard University Gazette.

Dezhbakhsh, H., Rubin, P., \& Shepherd, J. (2003). Does Capital Punishment Have a Deterrent Effect? New Evidence from Post-Moratorium Panel Data. American Law and Economics Review, 5(2), 344-376. 
Diaz, M. A., Hendey, G. W., \& Bivins, H. G. (2005, January). When Is the Helicopter Faster? A Comparison of Helicopter and Ground Ambulance Transport Times. Journal of Trauma-Injury Infection \& Critical Care, 58(1), 145-153.

Doerner, W. (1983, February). Why Does Johnny Reb Die when Shot? The Impact of medical Resources Upon Homicide. Sociological Inquiry, 53, 1-15.

Doerner, W. G. (1988, February). The Impact of Medical Resources Upon Criminally Induced Homicide: A Further Examination. Criminology, 26, 171-179.

Doerner, W., \& Speir, J. (1986, May). Stitch and Sew: The Impact of Medical Resources Upon Homicide. Criminology, 24, 319-330.

Donohue, J. J. (1998). Understanding the Time Path of Crime. The Journal of Criminal Law and Criminology, 88(4), 1423-1452.

Donohue, J., \& Levitt, S. D. (2001). The Impact of Legalized Abortion on Crime. Quarterly Journal of Economics, CXVI.2, 379-420.

Ehrlich, I. (1977). The Deterrent Effect of Capital Punishment: A Question of Life and Death. Journal of Political Economy, 85(4), 741-788.

Eisle, C. (2008). The Golden Hour. Journal of Emergency Medical Services.

Farley, R. (1980, May). Homicide Trends in the United States. Demography, 17(2).

FBI. (2014, October 11). Crime National or State Level. Retrieved October 11, 2014, from http://www.ucrdatatool.gov:

http://www.ucrdatatool.gov/Search/Crime/State/TrendsInOneVar.cfm

Federal Bureau of Investigation. (2011). Aggravated Assault. Retrieved October 28, 2014, from www.fbi.gov: http://www.fbi.gov/about-us/cjis/ucr/crime-in-the-u.s/2011/crime-in-the-u.s.2011/violent-crime/aggravated-assault

Federal Bureau of Investigation. (2012, December 1). Expanded Homicide Data Table. Retrieved April 24, 2013, from www.fbi.gov: http://www.fbi.gov/about-us/cjis/ucr/crime-in-the-u.s/2011/crimein-the-u.s.-2011/tables/expanded-homicide-data-table-8

Foig-Franzia, M. (2001, September 11). Washington Post.

Freeman, R. (1996). Why Do So Many Young Men Commit Crimes and What Might We Do About it? The Journal of Economic Perspectives, 10(1), 25-42.

Golub, A., \& Johnson, B. D. (1994). Tracking the Crack Epidemic in New York City using Data from the Drug Use Forecasting Program. National Institute of Justice, Office of Justice Programs. Rockville: National Institute of Justice.

Harris, A. R., Thomas, S. H., Fisher, G. A., \& Hirsch, D. J. (2002, May). Murder and Medicine: The Homicide of Criminal Assault 1960-1999. Homicide Studies, 6(2), 128-166.

Hatfield, D. N. (2002). A Report on Technical and Operational Issues Impacting the Provision of Wireless Enhanced 911 Services. Federal Communications Commission, FCC's Commercial Wireless Division of the Wireless Telecommunications Bureau . Washington: Federal Communications Commission.

Hodgetts, T. J., Mahoney, P. F., Russell, M. Q., \& Byers, M. (2006, Octover). ABC to <V>ABC: redefining the miliary trauma paradigm. Emergency Medicine Journal, 23(10), 745-746. 
Hoyert, D. L., \& Xu, J. (2012). Deaths: Preliminary Data for 2011. Centers for Disease Control and Prevention, National Center for Health Statistics. Washington: United States Government.

Joyce, T. J. (2009). A Simpe Test of Abortion and Crime. The Review of Economics and Statistics, 91(1), 112-123.

Klick, J., MacDonald, J., \& Stratmann, T. (2012). Mobile Phones and Crime Deterrence: An Underappreciated Link. Penn Law:Legal Scholarship Repository, Paper 426.

Lee, David and Thomas Lemieux. 2010. Regression Discontinuity Designs in Economics. Journal of Economic Literature, 48(2), June, 281-355.

Levitt, S. D. (2004). Understanding Why Crime Fell in the 1990s: Four Factors that Explain the Decline and Six that Do Not. Journal of Economic Perspectives, 18(1), 163-190.

Long-Onnen, J., \& Cheatwood, D. (1992). Hospitals and Homicide: An Expansion of Current Theoretical Paradigms. American Journal of Criminal Justice, 16, 57-74.

Martin, J. A., Hamilton, B. E., Ventura, S. J., Ostermand, M. J., Wilson, E. C., \& Mathews, T. J. (2012). Births: Final Data for 2010. National U.S. Department of Health and Human Services, National Center for Health Statistics. Washington: Centers for Disease Control and Prevention.

Marvell, T., \& Moody, C. (1996, November). Specification Problems, Police Levels, and Crime Rates. Criminology, 609-646.

Mayron, Ray, MD, Long, Robert S., MD, Ruiz, Ernest Ruiz, MD “The 911 Emergency Telephone Number: Impact on Emergency Medical Systems Access in a Metropolitan Area”, American Journal of Emergency Medicine, 1984, 2(6), 491-493.

National Association of Counties. (2014, October 15). Find a County. Retrieved October 15, 2015, from www.naco.org: http://www.naco.org/Counties/Pages/FindACounty.aspx

National Emergency Number Association. (2013). 9-1-1 Origin \& History. Retrieved April 9, 2013, from www.nena.org: http://www.nena.org/?page=911overviewfacts

Neumayer, E. (2003). Good Policy Can Lower Violent Crime: Evidence from a Cross-National Panel of Homicide Rates, 1980-1997. Journal of Peace Research, 40(6), 619-640.

Pridemore, William Alex. (2005) "A cautionary note on using county-level crime and homicide data." Homicide Studies, 9(3), 256-268.

Ventura, S. J. (2009). Changing Patterns of Nonmarital Childbearing in the United States. United States Government. Washington DC: Division of Vital Statistics.

Wright, R., Tekin, E., Topalli, V., McClellan, C., Dickinson, T., \& Rosenfeld, R. (2014, March). Less Cash, Less Crime: Evidence from the Electronic Benefit Transfer Program. Retrieved from National Bureau of Economic Research: http://www.nber.org/papers/w19996 
TABLE 1. SUMMARY STATISTICS

\begin{tabular}{|c|c|c|c|c|c|c|}
\hline Variables & Variable Description & $\begin{array}{l}\text { (1) } \\
\mathrm{N} \\
\end{array}$ & $\begin{array}{c}(2) \\
\text { Mean } \\
\end{array}$ & $\begin{array}{c}\text { (3) } \\
\text { Std. Dev. }\end{array}$ & $\begin{array}{l}\text { (4) } \\
\text { Min }\end{array}$ & $\begin{array}{l}\text { (5) } \\
\text { Max }\end{array}$ \\
\hline Pop. Density & $\begin{array}{l}\text { Population Density Per } \\
\text { Square Mile of Land }\end{array}$ & 5,603 & 4,464 & 3,194 & 300 & 19,790 \\
\hline Population & City Population & 5,603 & 430,017 & 481,390 & 88,632 & $3.907 e+06$ \\
\hline Income & $\begin{array}{l}\text { Real } 2000 \text { Per Capita Income } \\
\text { in 1000s }\end{array}$ & 5,603 & 18.59 & 5.569 & 2.440 & 62.97 \\
\hline White & Percent Population White & 5,603 & 68.50 & 16.81 & 9.900 & 99.10 \\
\hline Black & Percent Population Black & 5,603 & 21.35 & 16.81 & 0 & 83.20 \\
\hline Basic 911 & Basic 911 Dummy & 5,603 & 0.223 & 0.416 & 0 & 1 \\
\hline E911 & E911 Dummy & 5,603 & 0.304 & 0.460 & 0 & 1 \\
\hline GPS 911 & GPS 911 Dummy & 5,603 & 0.192 & 0.394 & 0 & 1 \\
\hline Cell Usage & $\begin{array}{l}\text { Percent of homes with cell } \\
\text { only }\end{array}$ & 5,603 & 5.345 & 12.45 & 0 & 67.80 \\
\hline Homicide & Level of Homicide Rate & 5,603 & 13.99 & 10.98 & 0 & 94.70 \\
\hline Rape & Level of Rape Rate & 5,603 & 52.28 & 31.39 & 0 & 215.1 \\
\hline Robbery & Level of Robbery Rate & 5,603 & 372.7 & 294.5 & 6.100 & 2,338 \\
\hline Assault & Level of Assault Rate & 5,603 & 483.8 & 361.4 & 4.500 & 2,700 \\
\hline Burglary & Level of Burglary Rate & 5,603 & 1,678 & 807.6 & 89 & 4,994 \\
\hline Larceny & Level of Larceny Rate & 5,603 & 3,906 & 1,476 & 143.6 & 10,052 \\
\hline Vehicle & Level of Vehicle Theft Rate & 5,603 & 821.1 & 579.2 & 48.30 & 5,369 \\
\hline Gun & $\begin{array}{l}\text { Percent of Assaults with } \\
\text { Guns }\end{array}$ & 5,497 & 26.54 & 12.35 & 0 & 78.50 \\
\hline Knife & $\begin{array}{l}\text { Percent of Assaults with } \\
\text { Knives }\end{array}$ & 5,497 & 24.88 & 9.352 & 0 & 78.70 \\
\hline Oweapon & $\begin{array}{l}\text { Percent of Assaults with } \\
\text { Other Weapons }\end{array}$ & 5,497 & 31.30 & 11.95 & 0 & 90.70 \\
\hline Person & $\begin{array}{l}\text { Percent of Assaults using } \\
\text { body parts }\end{array}$ & 5,497 & 17.28 & 13.10 & 0 & 89.20 \\
\hline
\end{tabular}

Notes: Data include annual observations from 112 cities between 1964 and 2014. For some of the earlier years in the sample, a few cities have missing observations for crime variables and weapon usage. 
TABLE 2. THE EFFECTS OF COMMUNICATION INNOVATIONS ON HOMICIDES

\begin{tabular}{|c|c|c|c|c|}
\hline & (1) & (2) & (3) & (4) \\
\hline Basic_911 & $\begin{array}{c}-0.163^{* * *} \\
(0.0396)\end{array}$ & $\begin{array}{c}-0.163^{* * *} \\
(0.0380)\end{array}$ & $\begin{array}{c}-0.170 * * * \\
(0.0368)\end{array}$ & $\begin{array}{c}-0.167 * * * \\
(0.0364)\end{array}$ \\
\hline E911 & $\begin{array}{c}-0.0322 \\
(0.0368)\end{array}$ & $\begin{array}{l}-0.0351 \\
(0.0365)\end{array}$ & $\begin{array}{l}-0.0396 \\
(0.0365)\end{array}$ & $\begin{array}{c}-0.0375 \\
(0.0365)\end{array}$ \\
\hline GPS_911 & $\begin{array}{c}-0.262 * * * \\
(0.0505)\end{array}$ & $\begin{array}{c}-0.271 * * * \\
(0.0505)\end{array}$ & $\begin{array}{c}-0.221 * * * \\
(0.0432)\end{array}$ & $\begin{array}{c}-0.218 * * * \\
(0.0428)\end{array}$ \\
\hline Ln Assault & $\begin{array}{c}0.182 * * * \\
(0.0277)\end{array}$ & $\begin{array}{c}0.255^{* * *} \\
(0.0296)\end{array}$ & $\begin{array}{c}0.222 * * * \\
(0.0299)\end{array}$ & $\begin{array}{c}0.221 * * * \\
(0.0300)\end{array}$ \\
\hline Gun & & $\begin{array}{c}0.0146 * * * \\
(0.00226)\end{array}$ & $\begin{array}{c}0.0133 * * * \\
(0.00209)\end{array}$ & $\begin{array}{c}0.0133^{* * *} \\
(0.00209)\end{array}$ \\
\hline Knife & & $\begin{array}{c}0.00500 * * \\
(0.00222)\end{array}$ & $\begin{array}{c}0.00461 * * \\
(0.00201)\end{array}$ & $\begin{array}{c}0.00449 * * \\
(0.00199)\end{array}$ \\
\hline Person & & $\begin{array}{c}0.00393 * * \\
(0.00152)\end{array}$ & $\begin{array}{c}0.00311^{* *} \\
(0.00141)\end{array}$ & $\begin{array}{c}0.00304 * * \\
(0.00140)\end{array}$ \\
\hline Black & & & $\begin{array}{c}0.0122 * * * \\
(0.00289)\end{array}$ & $\begin{array}{c}0.0120 * * * \\
(0.00291)\end{array}$ \\
\hline Pop Density & & & $\begin{array}{c}-1.89 e-05 \\
(1.65 e-05)\end{array}$ & $\begin{array}{c}-1.98 \mathrm{e}-05 \\
(1.65 \mathrm{e}-05)\end{array}$ \\
\hline Income & & & $\begin{array}{c}-0.0141 * * * \\
(0.00373)\end{array}$ & $\begin{array}{c}-0.0142 * * * \\
(0.00368)\end{array}$ \\
\hline Cell Usage & & & & $\begin{array}{c}-0.00447^{* *} \\
(0.00221)\end{array}$ \\
\hline Observations & 5,603 & 5,603 & 5,497 & 5,497 \\
\hline Adjusted R-squared & 0.340 & 0.405 & 0.438 & 0.439 \\
\hline City Fixed Effects & Yes & Yes & Yes & Yes \\
\hline Year Fixed Effects & Yes & Yes & Yes & Yes \\
\hline
\end{tabular}


TABLE 3. The EFFECTS OF COMMUNiCATION INNOVATIONS ON HoMicides - CiTY TRENDS

\begin{tabular}{|c|c|c|c|c|c|c|c|c|}
\hline \multirow{3}{*}{$\begin{array}{l}\text { Variables } \\
\text { Basic_911 }\end{array}$} & (1) & $(2)$ & (3) & (4) & (5) & (6) & (7) & (8) \\
\hline & \multicolumn{4}{|c|}{ Linear Trends } & \multicolumn{4}{|c|}{ Quadratic Trends } \\
\hline & $\begin{array}{c}-0.208^{* * *} \\
(0.0549)\end{array}$ & $\begin{array}{l}-0.111^{* *} \\
(0.0454)\end{array}$ & $\begin{array}{c}-0.0443 \\
(0.0406)\end{array}$ & $\begin{array}{c}-0.0544 \\
(0.0400)\end{array}$ & $\begin{array}{c}-0.275^{* * *} \\
(0.0545)\end{array}$ & $\begin{array}{c}-0.184 * * * \\
(0.0423)\end{array}$ & $\begin{array}{c}-0.168 * * * \\
(0.0361)\end{array}$ & $\begin{array}{c}-0.182^{* * *} \\
(0.0355)\end{array}$ \\
\hline E911 & $\begin{array}{c}-0.139 * * * \\
(0.0478)\end{array}$ & $\begin{array}{c}-0.112 * * \\
(0.0475)\end{array}$ & $\begin{array}{c}-0.155^{* * *} \\
(0.0404)\end{array}$ & $\begin{array}{c}-0.164^{* * *} \\
(0.0391)\end{array}$ & $\begin{array}{c}-0.154 * * * \\
(0.0457)\end{array}$ & $\begin{array}{c}-0.121 * * \\
(0.0477)\end{array}$ & $\begin{array}{c}-0.164 * * * \\
(0.0373)\end{array}$ & $\begin{array}{c}-0.125 * * * \\
(0.0357)\end{array}$ \\
\hline GPS_911 & $\begin{array}{c}-0.166 * * * \\
(0.0592)\end{array}$ & $\begin{array}{c}-0.198 * * * \\
(0.0443)\end{array}$ & $\begin{array}{c}-0.220 * * * \\
(0.0384)\end{array}$ & $\begin{array}{c}-0.190 * * * \\
(0.0426)\end{array}$ & $\begin{array}{l}-0.117^{*} \\
(0.0699)\end{array}$ & $\begin{array}{c}-0.125 * * \\
(0.0546)\end{array}$ & $\begin{array}{c}-0.0616 \\
(0.0451)\end{array}$ & $\begin{array}{c}-0.0896 * \\
(0.0467)\end{array}$ \\
\hline Log Assaults & $\begin{array}{c}0.559 * * * \\
(0.0526)\end{array}$ & $\begin{array}{c}0.558 * * * \\
(0.0403)\end{array}$ & $\begin{array}{c}0.360 * * * \\
(0.0301)\end{array}$ & $\begin{array}{c}0.357 * * * \\
(0.0303)\end{array}$ & $\begin{array}{c}0.556 * * * \\
(0.0602)\end{array}$ & $\begin{array}{c}0.552 * * * \\
(0.0449)\end{array}$ & $\begin{array}{c}0.316 * * * \\
(0.0329)\end{array}$ & $\begin{array}{c}0.308^{* * *} \\
(0.0329)\end{array}$ \\
\hline Controls & $\begin{array}{c}\text { As Col } 1 \\
\text { Table } 2\end{array}$ & $\begin{array}{c}\text { As Col } 2 \\
\text { Table } 2\end{array}$ & $\begin{array}{c}\text { As Col } 3 \\
\text { Table } 2\end{array}$ & $\begin{array}{c}\text { As Col } 4 \\
\text { Table } 2\end{array}$ & $\begin{array}{c}\text { As Col } 1 \\
\text { Table } 2\end{array}$ & $\begin{array}{c}\text { As Col } 2 \\
\text { Table } 2\end{array}$ & $\begin{array}{c}\text { As Col } 3 \\
\text { Table } 2\end{array}$ & $\begin{array}{c}\text { As Col } 4 \\
\text { Table } 2\end{array}$ \\
\hline City Fixed Effects & Yes & Yes & Yes & Yes & Yes & Yes & Yes & Yes \\
\hline Year Fixed Effects & Yes & Yes & Yes & Yes & Yes & Yes & Yes & Yes \\
\hline Adjusted R-squared & 0.604 & 0.717 & 0.788 & 0.789 & 0.625 & 0.729 & 0.805 & 0.807 \\
\hline
\end{tabular}


TABle 4. The EfFEcts of Communication InNOVAtions on Log Assaults

\begin{tabular}{|c|c|c|c|c|}
\hline & $(1)$ & $(2)$ & (3) & (4) \\
\hline Basic_911 & $\begin{array}{l}0.129 * * \\
(0.0516)\end{array}$ & $\begin{array}{l}0.109 * * \\
(0.0486)\end{array}$ & $\begin{array}{l}0.123 * * \\
(0.0531)\end{array}$ & $\begin{array}{c}0.0994 * * \\
(0.0486)\end{array}$ \\
\hline E911 & $\begin{array}{c}0.170 * * * \\
(0.0473)\end{array}$ & $\begin{array}{c}0.157 * * * \\
(0.0448)\end{array}$ & $\begin{array}{c}0.162 * * * \\
(0.0476)\end{array}$ & $\begin{array}{c}0.147 * * * \\
(0.0450)\end{array}$ \\
\hline GPS_911 & $\begin{array}{c}-0.154 * * \\
(0.0726)\end{array}$ & $\begin{array}{c}-0.146 * * \\
(0.0660)\end{array}$ & $\begin{array}{l}-0.131 * \\
(0.0712)\end{array}$ & $\begin{array}{l}-0.123^{*} \\
(0.0649)\end{array}$ \\
\hline Black & & & $\begin{array}{l}0.0100^{* *} \\
(0.00390)\end{array}$ & $\begin{array}{c}0.0102 * * * \\
(0.00386)\end{array}$ \\
\hline Pop Density & & & $\begin{array}{c}1.60 \mathrm{e}-05 \\
(1.54 \mathrm{e}-05)\end{array}$ & $\begin{array}{c}2.11 \mathrm{e}-05 \\
(1.62 \mathrm{e}-05)\end{array}$ \\
\hline Income & & & $\begin{array}{c}-0.0171^{* *} \\
(0.00729)\end{array}$ & $\begin{array}{c}-0.0183 * * * \\
(0.00684)\end{array}$ \\
\hline Cell Usage & & & $\begin{array}{l}0.000601 \\
(0.00459)\end{array}$ & $\begin{array}{l}-0.000876 \\
(0.00432)\end{array}$ \\
\hline Gun & & $\begin{array}{c}-0.0120 * * * \\
(0.00278)\end{array}$ & & $\begin{array}{c}-0.0128 * * * \\
(0.00283)\end{array}$ \\
\hline Knife & & $\begin{array}{c}-0.0174 * * * \\
(0.00292)\end{array}$ & & $\begin{array}{c}-0.0176^{* * * *} \\
(0.00292)\end{array}$ \\
\hline Person & & $\begin{array}{c}-0.00458 * * \\
(0.00214)\end{array}$ & & $\begin{array}{c}-0.00503^{* *} \\
(0.00216)\end{array}$ \\
\hline Observations & 5,603 & 5,497 & 5,603 & 5,497 \\
\hline Adjusted R-squared & 0.576 & 0.618 & 0.588 & 0.632 \\
\hline City Fixed Effects & Yes & Yes & Yes & Yes \\
\hline Year Fixed Effects & Yes & Yes & Yes & Yes \\
\hline
\end{tabular}




\begin{tabular}{|c|c|c|c|c|}
\hline & (1) & (2) & (3) & (4) \\
\hline & Robbery & Burglary & Larceny & Vehicle \\
\hline Basic 911 & $\begin{array}{l}0.00431 \\
(0.0430)\end{array}$ & $\begin{array}{c}0.0168 \\
(0.0372)\end{array}$ & $\begin{array}{c}0.0119 \\
(0.0305)\end{array}$ & $\begin{array}{c}-0.0332 \\
(0.0479)\end{array}$ \\
\hline E911 & $\begin{array}{c}0.0402 \\
(0.0405)\end{array}$ & $\begin{array}{c}-0.000724 \\
(0.0259)\end{array}$ & $\begin{array}{c}-0.00625 \\
(0.0208)\end{array}$ & $\begin{array}{l}-0.0243 \\
(0.0479)\end{array}$ \\
\hline GPS 911 & $\begin{array}{c}-0.105 \\
(0.0633)\end{array}$ & $\begin{array}{c}-0.119 * * \\
(0.0505)\end{array}$ & $\begin{array}{l}-0.0119 \\
(0.0463)\end{array}$ & $\begin{array}{l}-0.0848 \\
(0.0744)\end{array}$ \\
\hline Gun & $\begin{array}{c}0.00410^{* *} \\
(0.00167)\end{array}$ & $\begin{array}{c}0.000308 \\
(0.00161)\end{array}$ & $\begin{array}{r}-0.000806 \\
(0.00153)\end{array}$ & $\begin{array}{c}0.00672 * * * \\
(0.00176)\end{array}$ \\
\hline Knife & $\begin{array}{c}-0.00147 \\
(0.00215)\end{array}$ & $\begin{array}{c}-0.00309 \\
(0.00187)\end{array}$ & $\begin{array}{c}-0.00337 * * \\
(0.00148)\end{array}$ & $\begin{array}{c}-0.000199 \\
(0.00260)\end{array}$ \\
\hline Person & $\begin{array}{l}-0.00245 \\
(0.00152)\end{array}$ & $\begin{array}{c}-0.00271^{*} \\
(0.00159)\end{array}$ & $\begin{array}{c}-0.00361 * * * \\
(0.000959)\end{array}$ & $\begin{array}{r}-0.000373 \\
(0.00163)\end{array}$ \\
\hline Black & $\begin{array}{c}0.0204^{* * *} \\
(0.00617)\end{array}$ & $\begin{array}{c}0.0171^{* * *} \\
(0.00425)\end{array}$ & $\begin{array}{c}0.00787 * * \\
(0.00350)\end{array}$ & $\begin{array}{c}0.00690 \\
(0.00508)\end{array}$ \\
\hline Pop. Density & $\begin{array}{c}3.02 \mathrm{e}-05 \\
(2.72 \mathrm{e}-05)\end{array}$ & $\begin{array}{c}-2.91 \mathrm{e}-05 \\
(2.16 \mathrm{e}-05)\end{array}$ & $\begin{array}{c}-5.22 \mathrm{e}-05^{* * *} \\
(1.68 \mathrm{e}-05)\end{array}$ & $\begin{array}{c}1.99 \mathrm{e}-05 \\
(2.57 \mathrm{e}-05)\end{array}$ \\
\hline Income & $\begin{array}{l}-0.00285 \\
(0.00657)\end{array}$ & $\begin{array}{c}-0.0144^{*} \\
(0.00761)\end{array}$ & $\begin{array}{l}-7.26 e-05 \\
(0.00511)\end{array}$ & $\begin{array}{c}-0.00875 \\
(0.00738)\end{array}$ \\
\hline Cell Usage & $\begin{array}{c}0.00410 \\
(0.00343)\end{array}$ & $\begin{array}{c}0.00825 * \\
(0.00420)\end{array}$ & $\begin{array}{c}0.00604^{* *} \\
(0.00263)\end{array}$ & $\begin{array}{c}0.0135 * * * \\
(0.00423)\end{array}$ \\
\hline City Fixed Effects & Yes & Yes & Yes & Yes \\
\hline Year Fixed Effects & Yes & Yes & Yes & Yes \\
\hline Observations & 5,497 & 5,497 & 5,497 & 5,497 \\
\hline Adjusted R-squared & 0.632 & 0.658 & 0.567 & 0.454 \\
\hline
\end{tabular}

Notes: Statistical significance at the $0.10,0.05$, and 0.01 levels are indicated by $*, * *$, and ${ }^{* * *}$. Standard errors clustered at the city level in parentheses. The heading of each column indicates the dependent variable used in the specification reported in that column. All dependent variables are measured in logs. For the types of weapons used, the left-out category is 'other weapon'. The falsification test in column (4) uses a placebo for each of the four 911 variables with a five-year lead. 
TABLE 6. EVENT STUDY RESULTS: HOMICIDES

\begin{tabular}{|c|c|c|c|}
\hline & $\begin{array}{c}(1) \\
\text { Homicides } \\
\text { Basic } 911\end{array}$ & $\begin{array}{c}(2) \\
\text { Homicides } \\
\text { E911 }\end{array}$ & $\begin{array}{c}(4) \\
\text { Homicides } \\
\text { GPS } 911\end{array}$ \\
\hline \multicolumn{4}{|l|}{ Linear Trend } \\
\hline Emergency Service & $\begin{array}{c}-0.162 * * * \\
(0.0453)\end{array}$ & $\begin{array}{c}-0.201^{* * *} \\
(0.0368)\end{array}$ & $\begin{array}{c}0.309 * * * \\
(0.0333)\end{array}$ \\
\hline Adjusted R Squared & 0.127 & 0.213 & 0.262 \\
\hline \multicolumn{4}{|l|}{ Quadratic Trend } \\
\hline Emergency Service & $\begin{array}{c}-0.157 * * * \\
(0.0449)\end{array}$ & $\begin{array}{c}-0.205^{* * *} \\
(0.0389)\end{array}$ & $\begin{array}{l}0.286 * * * \\
(0.0327)\end{array}$ \\
\hline Adjusted R Squared & 0.126 & 0.212 & 0.267 \\
\hline \multicolumn{4}{|l|}{ Two Linear Trends } \\
\hline Emergency Service & $\begin{array}{c}-0.183 * * \\
(0.0759)\end{array}$ & $\begin{array}{c}-0.175^{* * *} \\
(0.0554)\end{array}$ & $\begin{array}{l}0.463 * * * \\
(0.0779)\end{array}$ \\
\hline Adjusted R Squared & 0.126 & 0.212 & 0.268 \\
\hline Observations & 782 & 776 & 629 \\
\hline Cities & 112 & 112 & 94 \\
\hline Year Controls & Yes & Yes & Yes \\
\hline City Controls & Yes & Yes & Yes \\
\hline Socioeconomic & Yes & Yes & Yes \\
\hline
\end{tabular}

Notes. The emergency service is coded as " 0 " for years prior to implementation and as " 1 " otherwise. Three years are included before the launch of the service, followed by the launch year and the three years following. In all regressions, standard errors are clustered at the city level. Clustered standard errors in parentheses. 
Table 7. Event Study Results: Aggravated Assaults

\begin{tabular}{|c|c|c|c|}
\hline & $\begin{array}{c}(1) \\
\text { Assaults } \\
\text { Basic } 911\end{array}$ & $\begin{array}{c}(2) \\
\text { Assaults } \\
\text { E911 }\end{array}$ & $\begin{array}{c}\text { (3 } \\
\text { Assaults } \\
\text { GPS } 911\end{array}$ \\
\hline \multicolumn{4}{|l|}{ Linear Trend } \\
\hline Emergency Service & $\begin{array}{c}0.0790 * * * \\
(0.0278)\end{array}$ & $\begin{array}{c}0.0616^{* *} \\
(0.0297)\end{array}$ & $\begin{array}{c}0.0555 * * \\
(0.0257)\end{array}$ \\
\hline Adjusted R Squared & 0.507 & 0.327 & 0.098 \\
\hline \multicolumn{4}{|l|}{ Quadratic Trend } \\
\hline Emergency Service & $\begin{array}{c}0.0799 * * * \\
(0.0278)\end{array}$ & $\begin{array}{c}0.0814^{* * *} \\
(0.0287)\end{array}$ & $\begin{array}{c}0.039 \\
(0.0268)\end{array}$ \\
\hline Adjusted R Squared & 0.506 & 0.33 & 0.101 \\
\hline \multicolumn{4}{|l|}{2 Linear Trends } \\
\hline Emergency Service & $\begin{array}{c}0.0701 \\
(0.0663)\end{array}$ & $\begin{array}{c}-0.0432 \\
(0.0594)\end{array}$ & $\begin{array}{l}0.159 * * \\
(0.0678)\end{array}$ \\
\hline Adjusted R Squared & 0.506 & 0.331 & 0.102 \\
\hline Observations & 782 & 776 & 629 \\
\hline Cities & 112 & 112 & 94 \\
\hline Year Effects & Yes & Yes & Yes \\
\hline City Effects & Yes & Yes & Yes \\
\hline Socioeconomic & Yes & Yes & Yes \\
\hline
\end{tabular}

Notes. The emergency service is coded as "0" for years prior to implementation and as "1" otherwise. Three years are included before the launch of the service, followed by the launch year and the three years following. In all regressions, standard errors are clustered at the city level. Clustered standard errors in parentheses. 
Figure 1. Changes in U.S. Aggravated Assault and Homicide Rates (1964 To 2014)

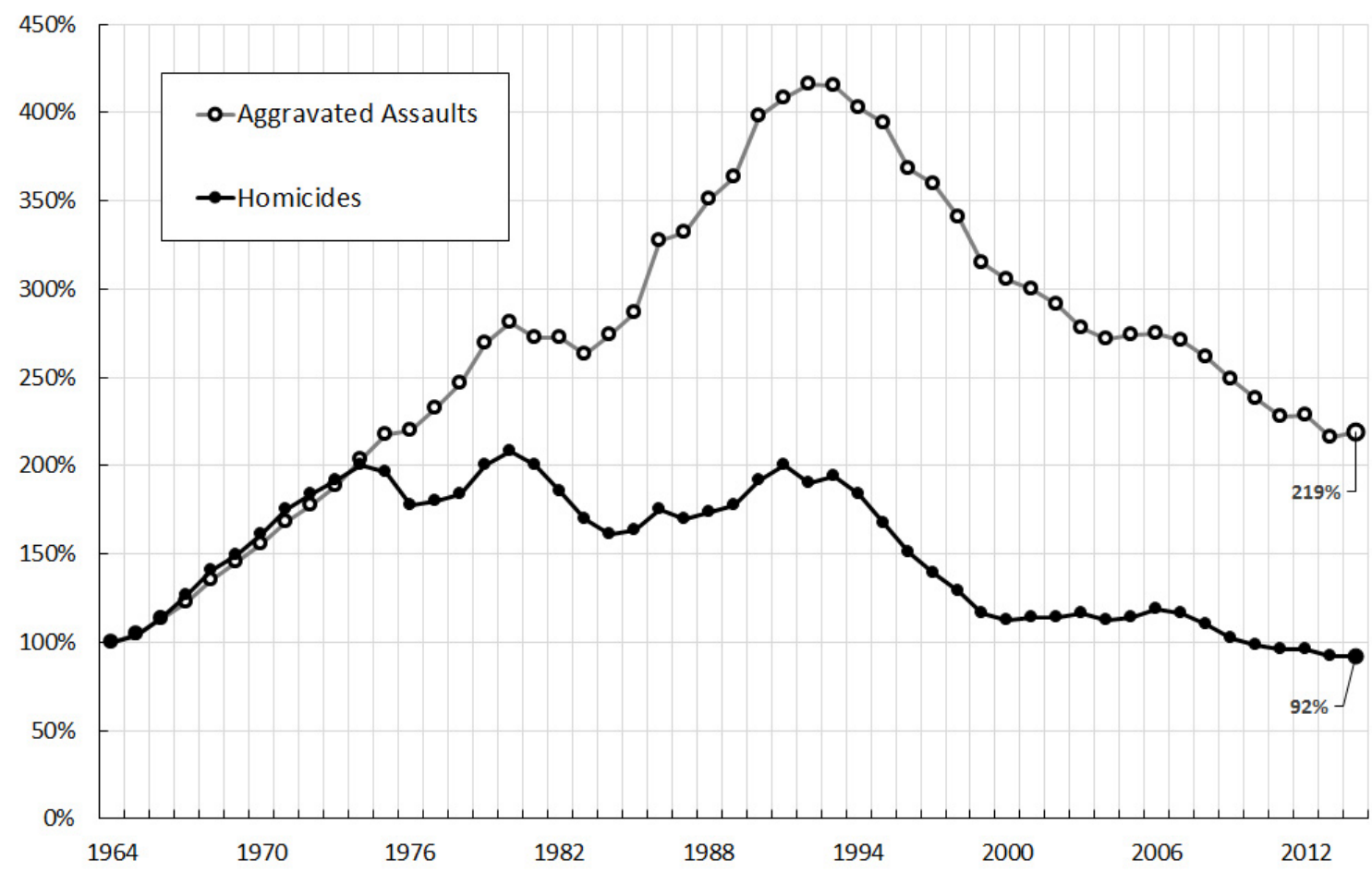

Notes: The vertical axis measures the percentage change in homicide and aggravated assault rates relative to 1964, which is the base year in this Figure. Homicide and aggravated assault rates equal the number of national homicides and aggravated assaults per 100,000 residents in the US for the given year. Data for this graph come from the Federal Bureau of Investigation (FBI) Uniform Crime Reports (UCR). 
Figure 2. Rollout Dates of 911 SeRVices In 112 Major U.S. Cities

Launch Dates of 9-1-1 Services Across 112 Major Cities

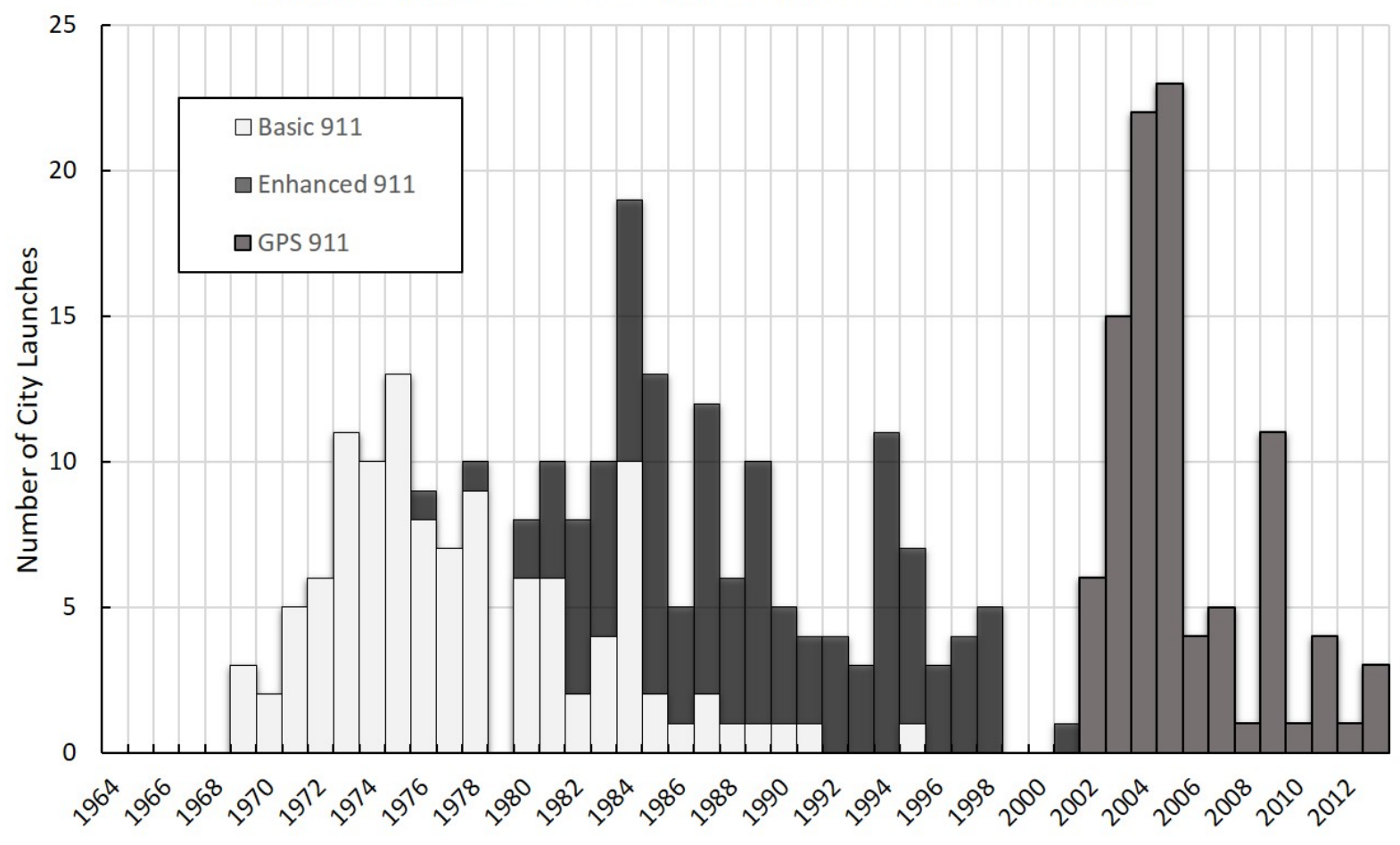

SOURCES: Newspaper Articles, Phone Conversations, Emails, and Call Center Websites.

Notes: The vertical axis shows the number of cities having adopted each of the 911 iterations. The horizontal axis indicates the date a city adopted a service. Sources for these data are newspaper articles, phone interviews, emails and phone calls to city call centers. All sources are documented and available upon request. 
Figure 3. Percentage Of U.S. Aggravated Assaults Using Guns (1964 to 2014)

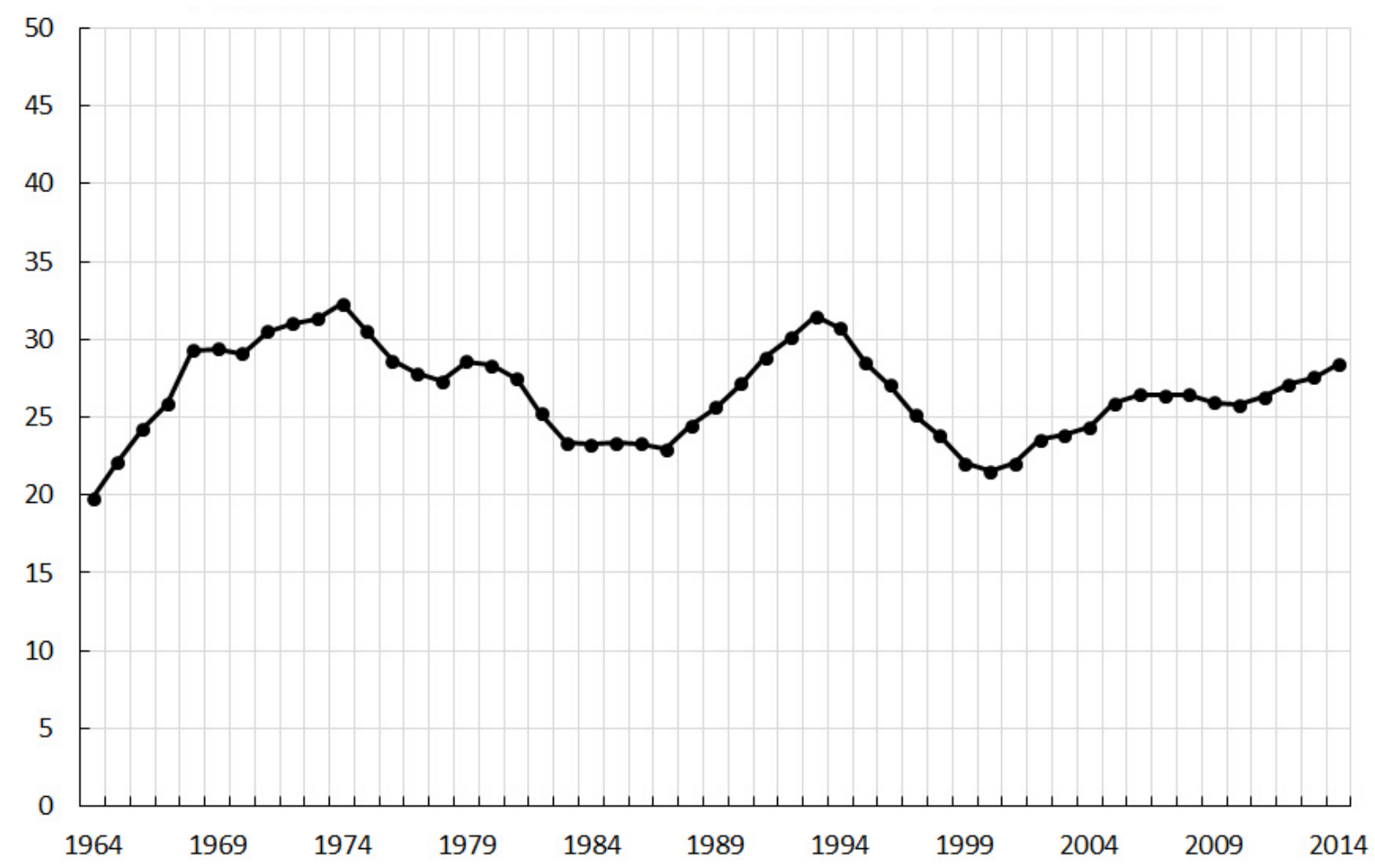

Notes: Data for this figure come from the weapon data in the annual crime reports provided by the Federal Bureau of Investigation (FBI). The series in the figure represents the sample of 112 cities analyzed in this paper. 
Figure 4. TREATMENT EFFECTS FOR THE HoMiCide REgRESSIONS CORRESPONDING TO TABLE 2, COLUMN 4

PANEL A

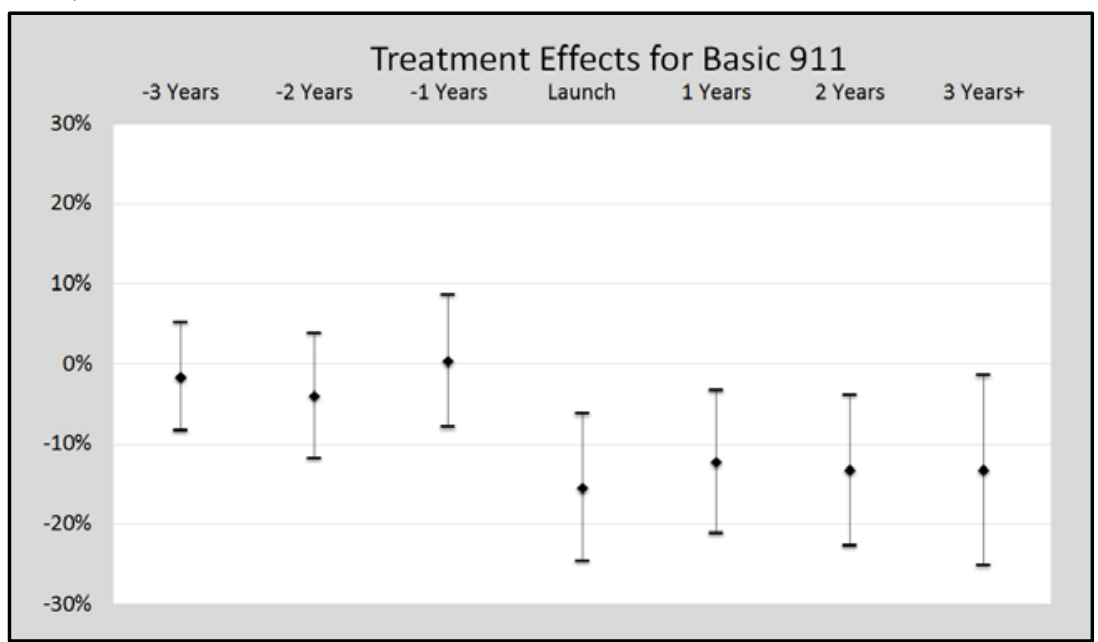

PANEL B

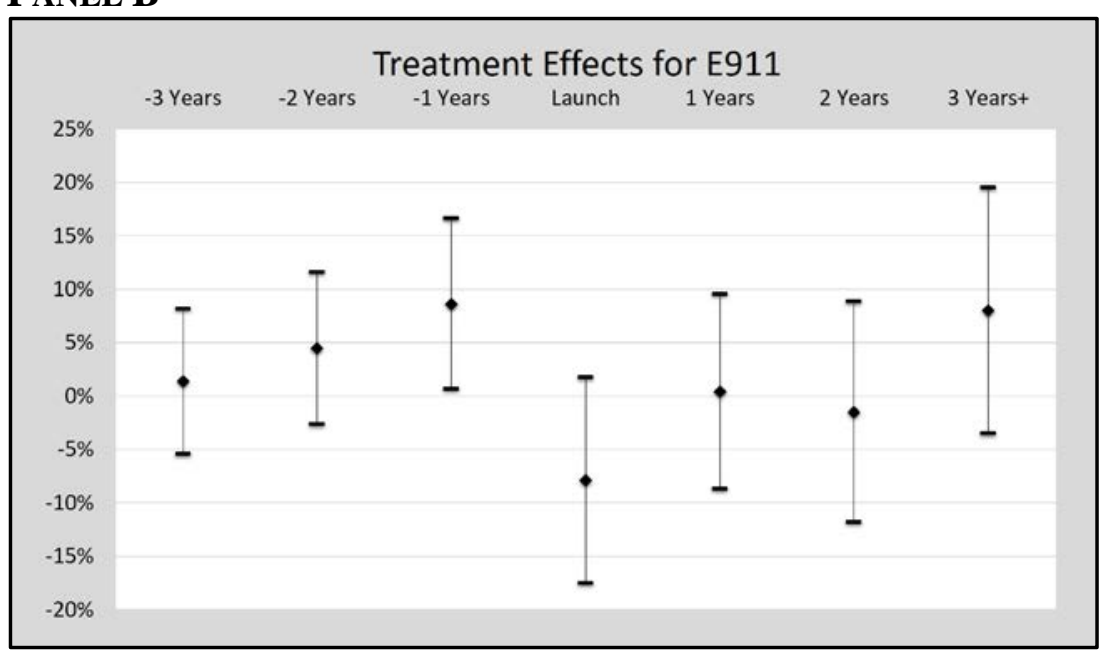

PANel C

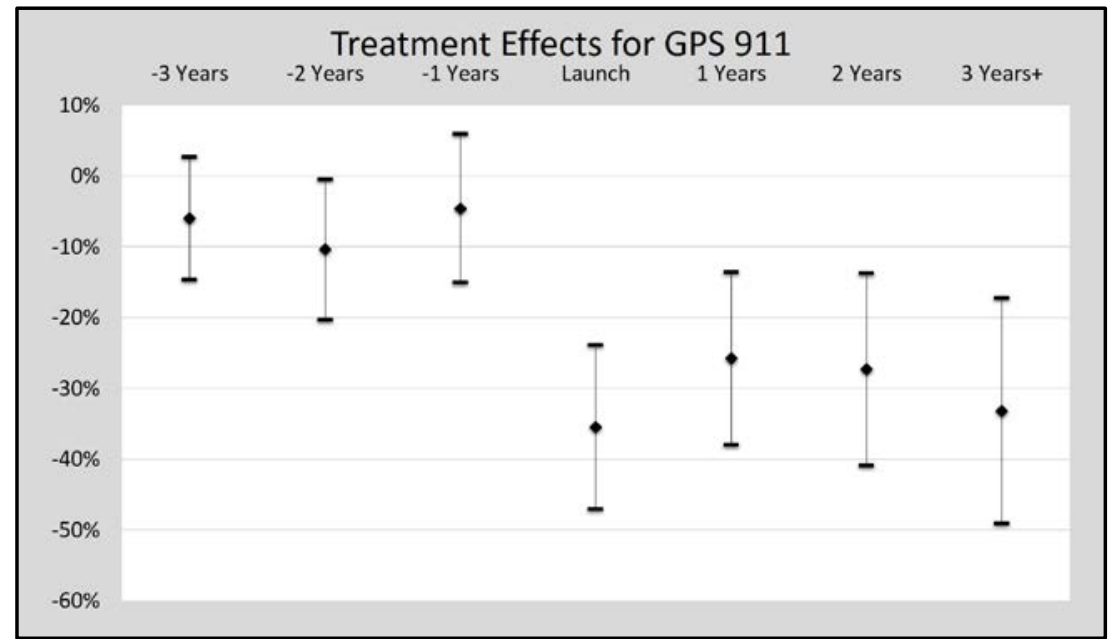

Notes: The diamonds show point estimates and the whiskers show 95 percent confidence intervals. Control variables in these regressions are identical with those in Table 2, column 4. Standard errors are clustered at the city level. 


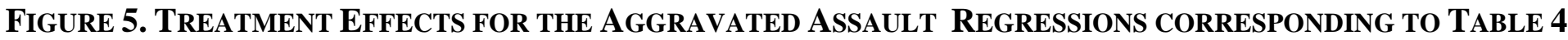

PANEL A

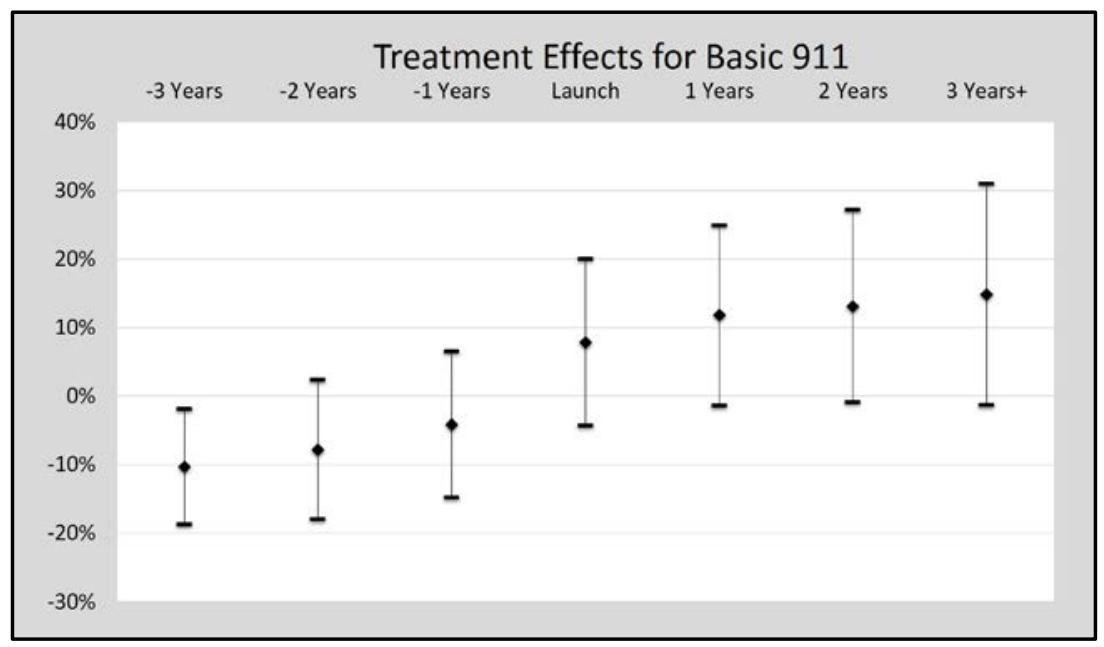

PANEL B

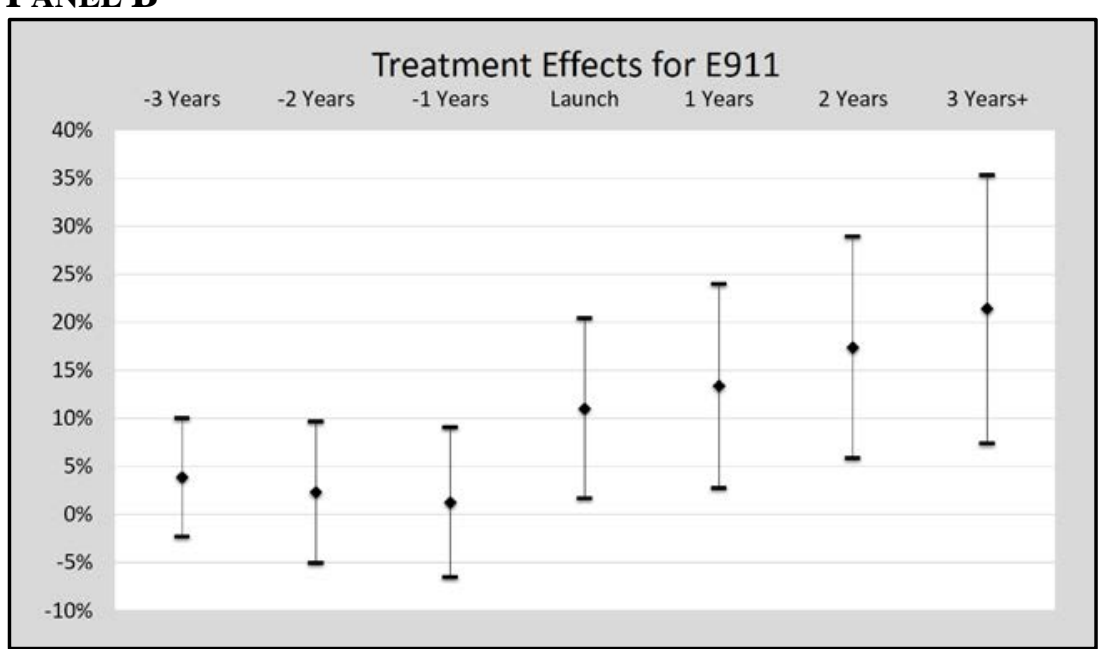

\section{Panel C}

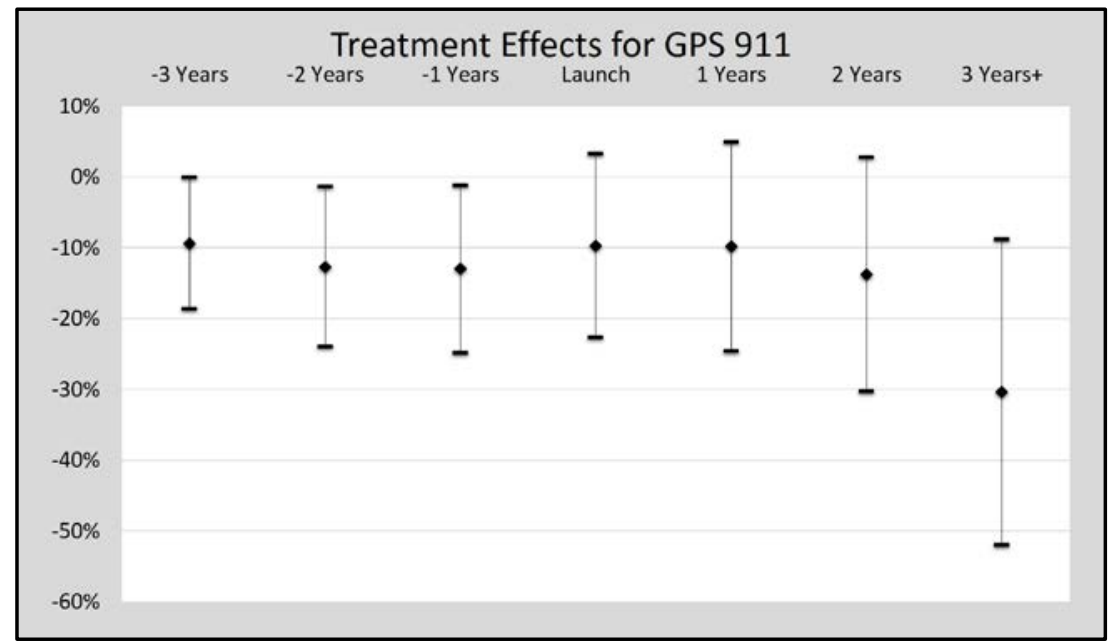

Notes: The diamonds show point estimates and the whiskers show 95 percent confidence intervals. Control variables in these regressions are identical with those in Table 4, column 2. Standard errors are clustered at the city level. 
FiguRE 6. EVENT STUDIES GRAPHS CORRESPONDING TO TABLE 6: HOMICIDES - TWO LiNEAR TRENDS

Panel A

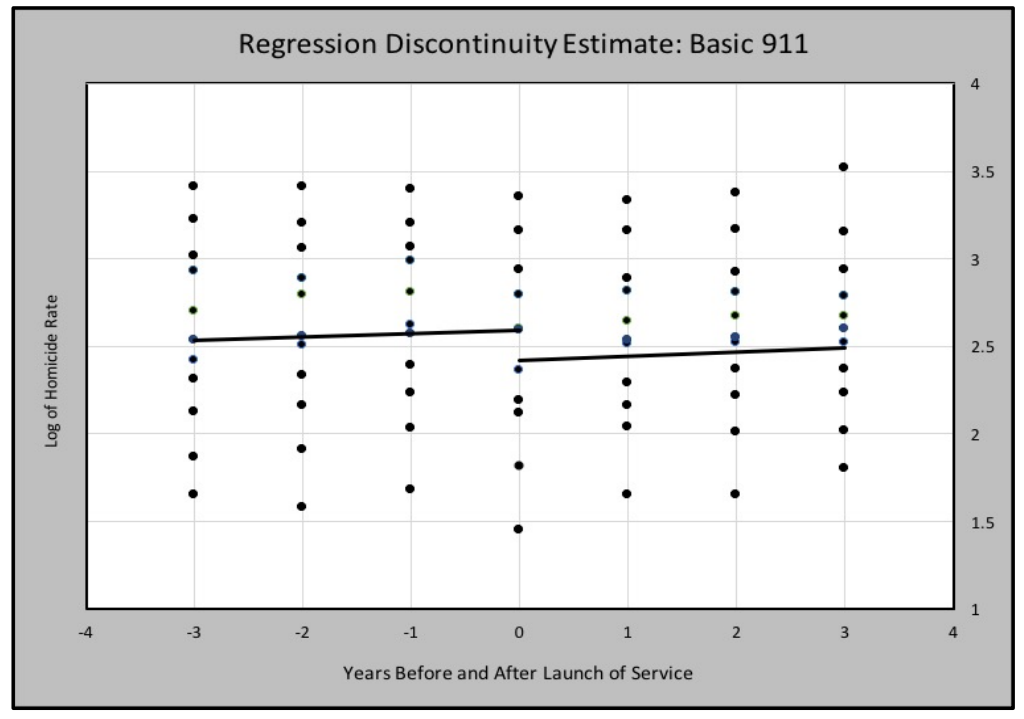

PANEL B

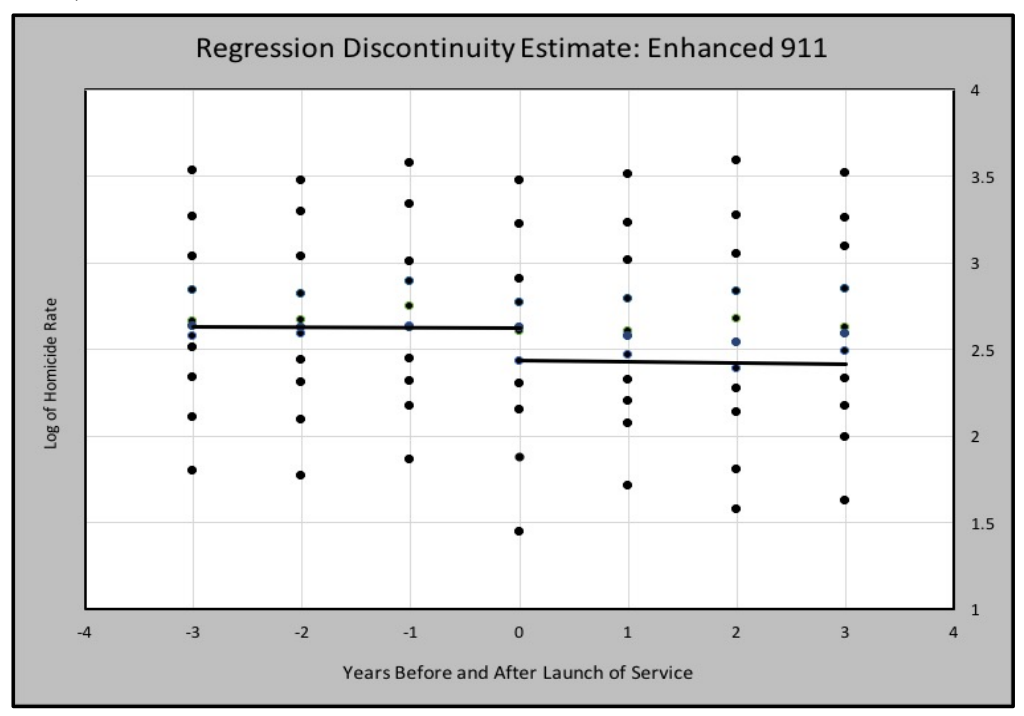

PANEL C

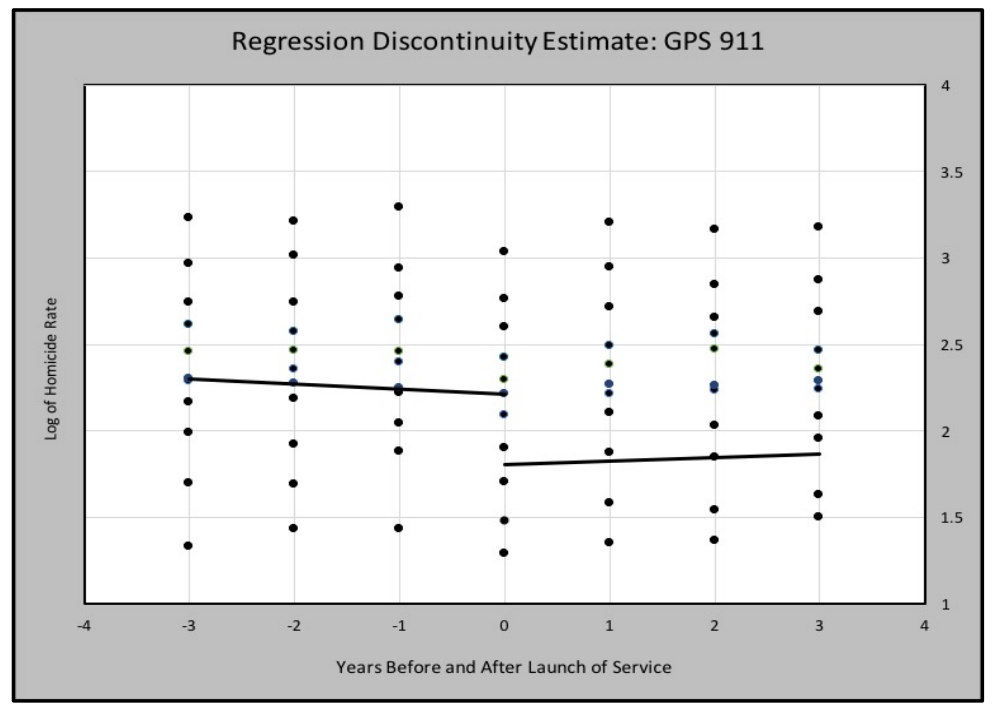


Figure 7. Event Studies Graphs CorResponding to TABle 7: Aggravated Assaults - Two LineAR TRENDS

PANEL A

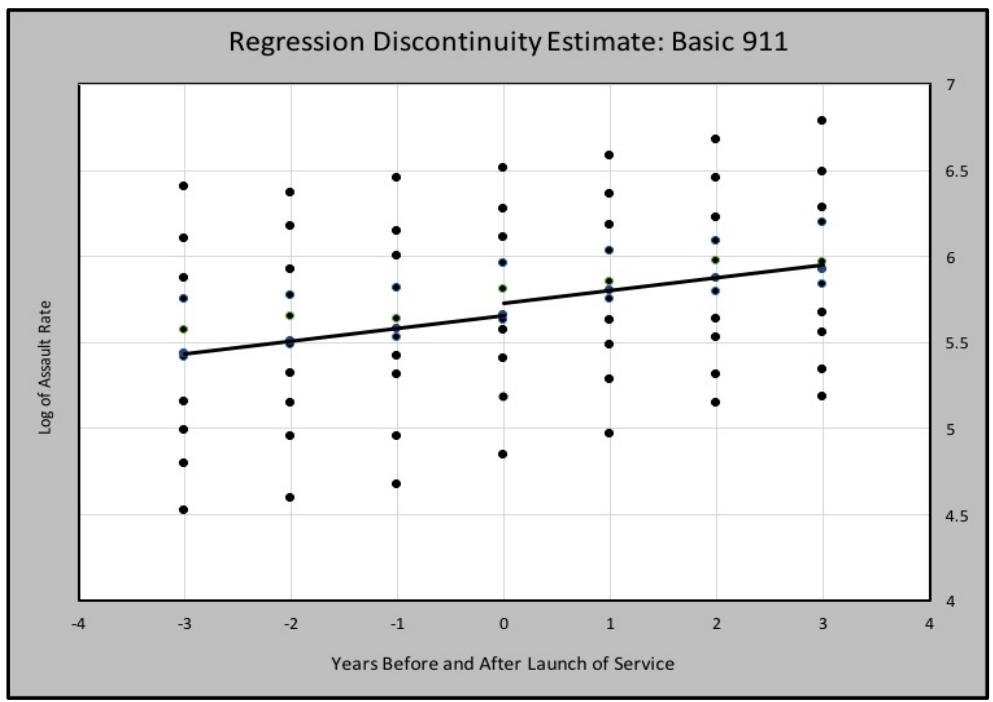

\section{PANEL B}

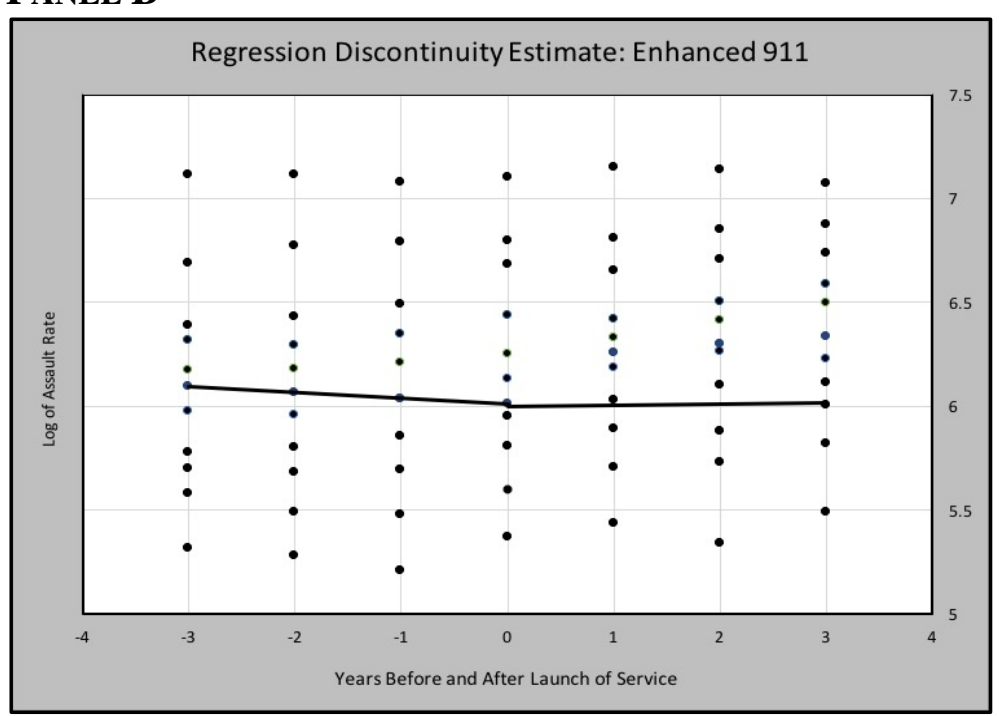

PANEl C

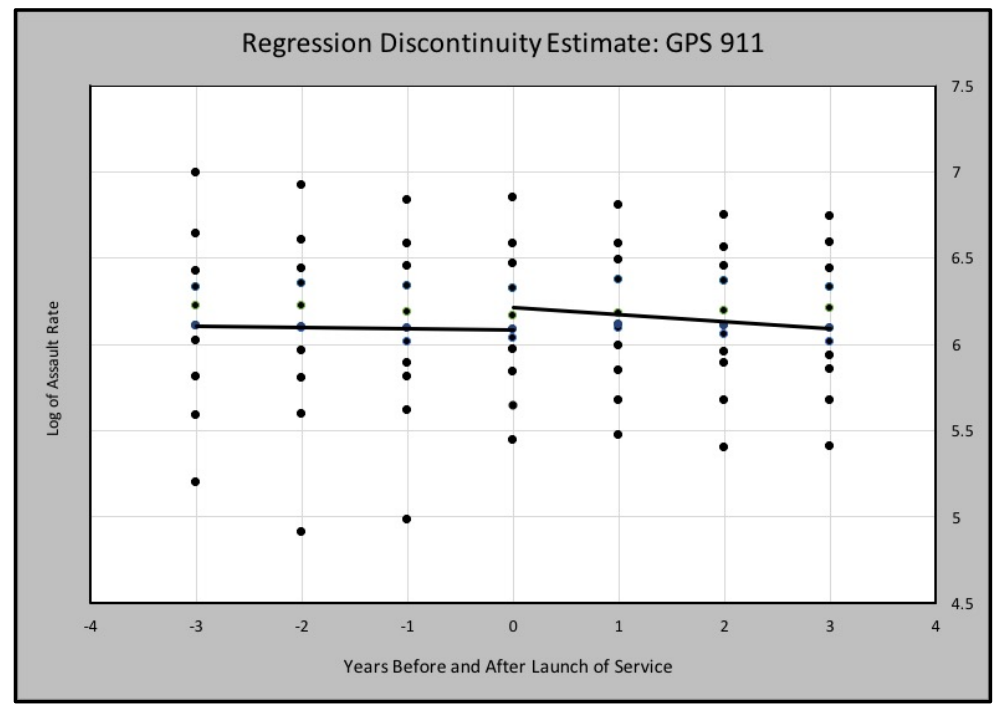


Figure 8. Homicide Growth Rates for Mobile, Alabama

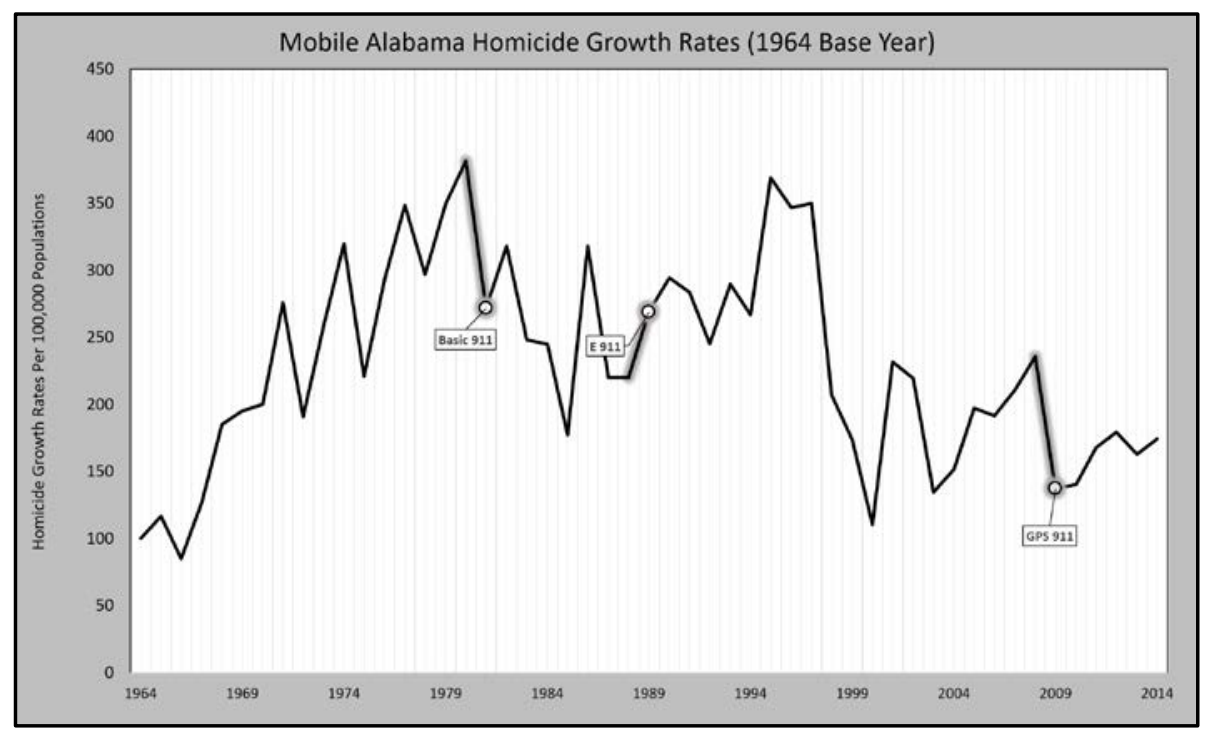

Notes. The vertical axis measures the percentage change in homicide rates of the city of Mobile, Alabama for the years 1964 to 2014, relative to the base year of 1964. The data came from police reports filed by the Mobile Police Department with the Federal Bureau of Investigation (FBI). The graph shows the implementation dates of Basic 911, E911, and GPS 911.

\section{Figure 9. HOMICIDE GROWTH RATES FOR CinCINNATI, OHIO}

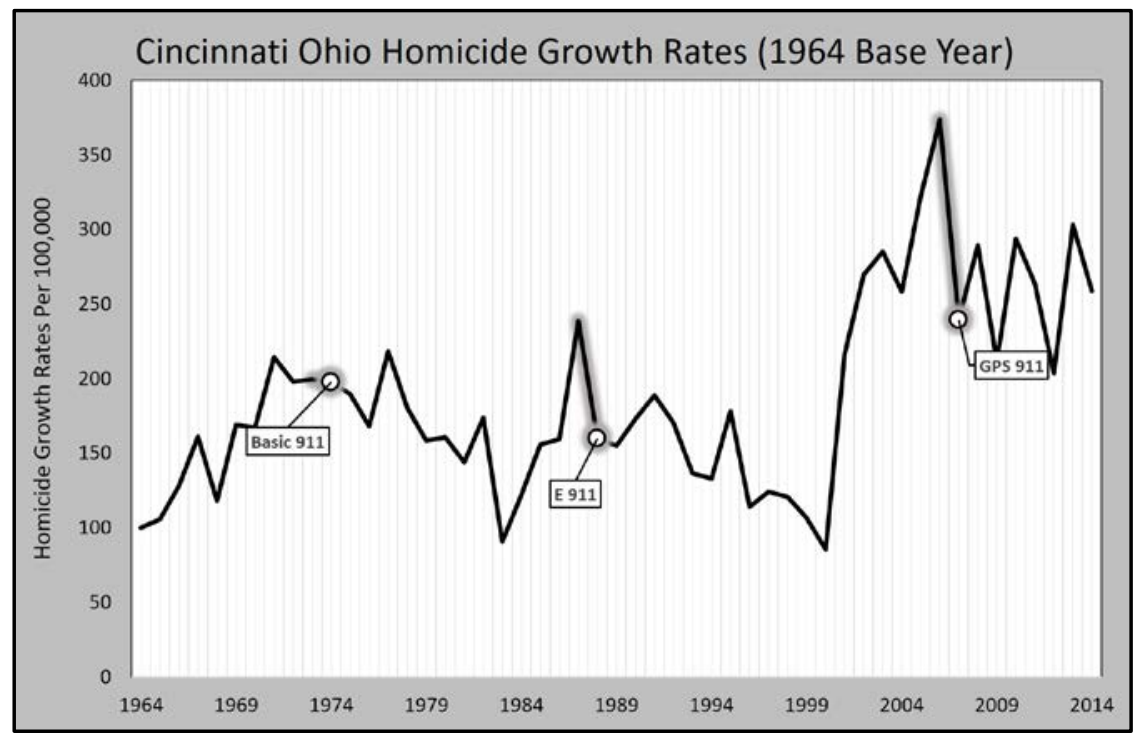

Notes. The vertical axis measures the percentage change in homicide rates of the city of Cincinnati, Ohio for the years 1964 to 2014, relative to the base year of 1964. The data came from police reports filed by the Cincinnati Police Department with the Federal Bureau of Investigation (FBI). The graph shows the implementation dates of Basic 911, E911, and GPS 911. 


\section{APPENDIX}

TABLE A1: SAMPle STATES AND CITIES

STATE

Alabama

Alaska

Arizona

Arkansas

California

Colorado

Washington DC

Florida

\section{Georgia}

Illinois

Indiana

Iowa

Kansas

Kentucky
CITY

Birmingham

Huntsville

Mobile

Montgomery

Anchorage

Phoenix

Tucson

Little Rock

Anaheim

Bakersfield

Fremont

Fresno

Glendale

Huntington Beach

Long Beach

Los Angeles

Oakland

Riverside

Sacramento

San Bernardino

San Diego

San Francisco

San Jose

Santa Ana

Stockton

Colorado Springs

Denver

District of Columbia

Hialeah

Jacksonville

Miami

Orlando

St Petersburg

Tampa

Atlanta

Columbus

Chicago

Fort Wayne

Indianapolis

Des Moines

Wichita

Lexington

Louisville
STATE

Louisiana

Maryland

Massachusetts

Michigan

Minnesota

Mississippi

Missouri

Nebraska

Nevada

New Jersey

New Mexico

New York

Ohio

North Carolina

Oklahoma
Oregon
Pennsylvania
Rhode Island

\section{CITY}

Baton Rouge

New Orleans

Shreveport

Baltimore

Boston

Springfield

Worcester

Detroit

Flint

Grand Rapids

Minneapolis

St Paul

Jackson

Kansas City

Saint Louis

Springfield

Lincoln

Omaha

Las Vegas

Jersey City

Newark

Albuquerque

Buffalo

Rochester

Yonkers

Charlotte

Greensboro

Raleigh

Winston-Salem

Akron

Cincinnati

Cleveland

Columbus

Dayton

Toledo

Oklahoma City

Tulsa

Portland

Philadelphia

Pittsburgh

Providence 
STATE

Tennessee

Texas

\section{CITY}

Chattanooga

Knoxville

Memphis

Nashville

Amarillo

Arlington

Austin

Corpus Christi

Dallas

El Paso

Ft Worth

Garland

Houston

Irving

Lubbock

\section{STATE}

Utah

Virginia

Washington

Wisconsin

\section{CITY}

San Antonio

Salt Lake City

Arlington

Tarrant County

Chesapeake

Newport News

Norfolk

Richmond

Virginia Beach

Seattle

Spokane

Tacoma

Madison

Milwaukee 